\title{
DUBs Activating the Hedgehog Signaling Pathway: A Promising Therapeutic Target in Cancer
}

\author{
Francesca Bufalieri ${ }^{1}{ }^{(0)}$, Ludovica Lospinoso Severini ${ }^{1}{ }^{\circledR}$, Miriam Caimano ${ }^{1}$, Paola Infante ${ }^{2, *}$ \\ and Lucia Di Marcotullio 1,3,*(D) \\ 1 Department of Molecular Medicine, Sapienza University, Viale Regina Elena 291, 00161 Rome, Italy; \\ francesca.bufalieri@uniroma1.it (F.B.); ludovica.lospinososeverini@uniroma1.it (L.L.S.); \\ miriam.caimano@uniroma1.it (M.C.) \\ 2 Center for Life Nano Science@Sapienza, Istituto Italiano di Tecnologia, Viale Regina Elena 291, \\ 00161 Rome, Italy \\ 3 Laboratory Affiliated to Istituto Pasteur Italia-Fondazione Cenci Bolognetti, Department of Molecular \\ Medicine, Sapienza University, Viale Regina Elena 291, 00161 Rome, Italy \\ * Correspondence: paola.infante@iit.it (P.I.); lucia.dimarcotullio@uniroma1.it (L.D.M.); \\ Tel.: +39-06-49255132 (P.I.); +39-06-49255657 (L.D.M.); Fax: +39-06-49255660 (L.D.M.)
}

Received: 2 May 2020; Accepted: 6 June 2020; Published: 10 June 2020

\begin{abstract}
The Hedgehog $(\mathrm{HH})$ pathway governs cell proliferation and patterning during embryonic development and is involved in regeneration, homeostasis and stem cell maintenance in adult tissues. The activity of this signaling is finely modulated at multiple levels and its dysregulation contributes to the onset of several human cancers. Ubiquitylation is a coordinated post-translational modification that controls a wide range of cellular functions and signaling transduction pathways. It is mediated by a sequential enzymatic network, in which ubiquitin ligases (E3) and deubiquitylase (DUBs) proteins are the main actors. The dynamic balance of the activity of these enzymes dictates the abundance and the fate of cellular proteins, thus affecting both physiological and pathological processes. Several E3 ligases regulating the stability and activity of the key components of the $\mathrm{HH}$ pathway have been identified. Further, DUBs have emerged as novel players in $\mathrm{HH}$ signaling transduction, resulting as attractive and promising drug targets. Here, we review the HH-associated DUBs, discussing the consequences of deubiquitylation on the maintenance of the $\mathrm{HH}$ pathway activity and its implication in tumorigenesis. We also report the recent progress in the development of selective inhibitors for the DUBs here reviewed, with potential applications for the treatment of $\mathrm{HH}$-related tumors.
\end{abstract}

Keywords: ubiquitylation; DUBs; Hedgehog pathway; cancer; targeted therapy

\section{The HH Signaling Pathway and Tumorigenesis: An Overview}

The HH pathway is a mitogen and morphogen signaling, conserved from Drosophila to mammals. It plays a crucial role in organogenesis and central nervous system (CNS) development [1,2]. In post-embryonic stages, $\mathrm{HH}$ signaling regulates tissue homeostasis and repair, modulating the specification of the adult stem cells [3,4]. Several studies have highlighted similarities and divergences between Drosophila and mammals $\mathrm{HH}$ signal transduction (Figure 1A,B). Both in flies and in vertebrates the $\mathrm{HH}$ pathway activation is finely orchestrated by two membrane receptors: the multi-pass transmembrane protein Patched (Ptc/PTCH) and the heptahelical transmembrane co-receptor Smoothened (Smo/SMO). In Drosophila, in absence of the Hh ligand, Ptc keeps off the signaling by directly affecting Smo activity and preventing its accumulation on the plasma membrane. In this state, Costal-2 (Cos2; Costa-FlyBase), a kinesin family protein, Fused (Fu), a serine-threonine kinase and the Suppressor of fused $[\mathrm{Su}(\mathrm{fu})]$ inhibit the bifunctional transcription factor Cubitus interrupts 
(Ci), endowed of both repressor and activator domains. The full-length $\mathrm{Ci}$ protein is proteolytically processed by the Skp1-Cullin1-Slimb (SCFSlimb) ubiquitin ligase complex, in a truncated form $\left(\mathrm{Ci}^{\mathrm{R}}\right)$ that acts as transcriptional repressor of Hh target genes when translocated into the nucleus (Figure $1 \mathrm{~A})[5,6]$.

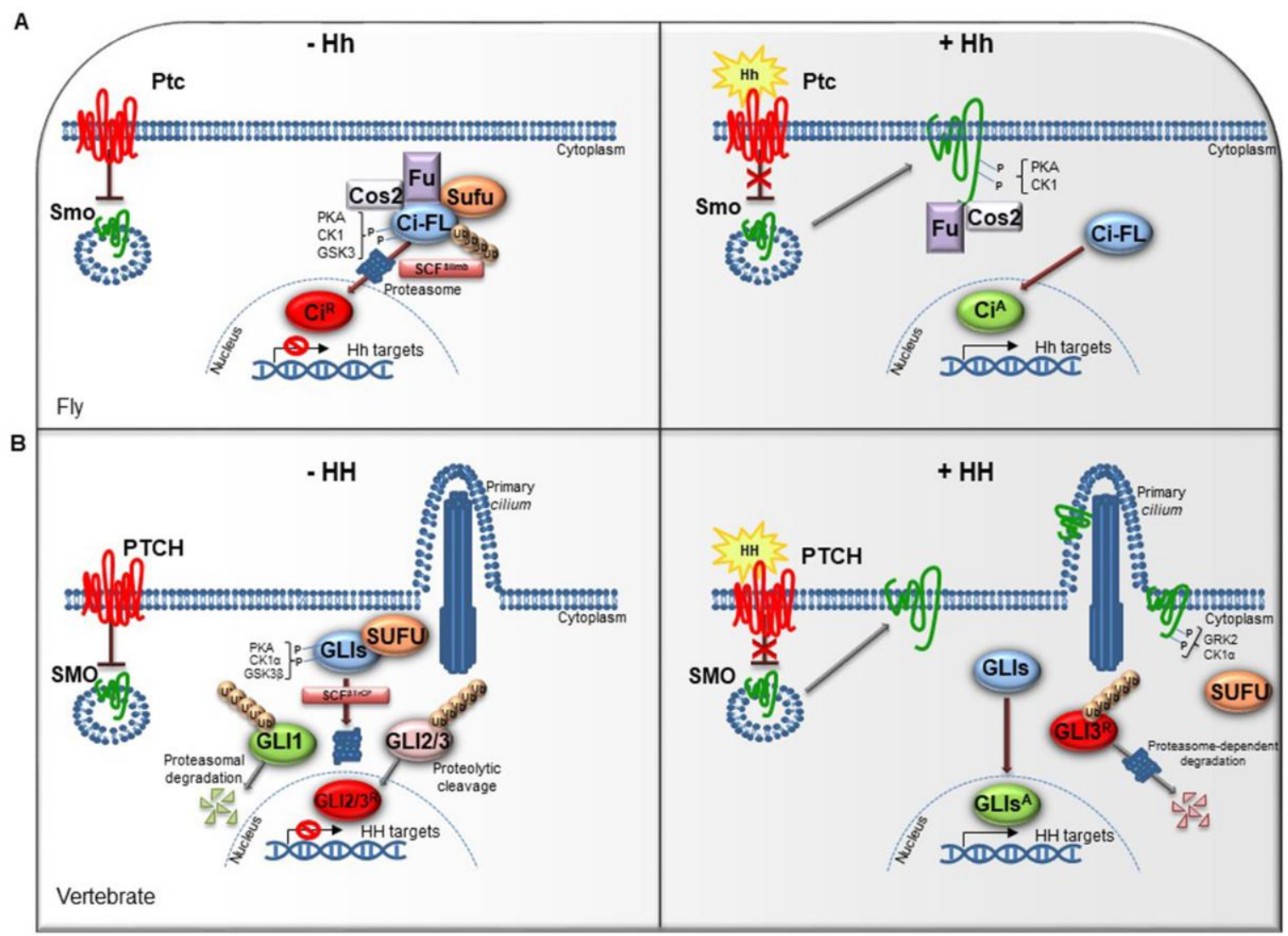

Figure 1. The Hedgehog signaling pathway. (A) The Hedgehog signaling pathway in fly. In absence of $\mathrm{Hh}$, Ptc inhibits the localization of Smo on cell membrane. In the cytoplasm, Cos2, Fu and Sufu assemble in complex with Ci-FL protein, favoring its phosphorylation by PKA, CK1, and GSK3. This event induces the Ci-FL ubiquitylation by SCFSlimb E3 ligase thus leading both to proteasome degradation and cleavage into truncated repressor form $\left(\mathrm{Ci}^{\mathrm{R}}\right) \cdot \mathrm{Ci}^{\mathrm{R}}$ blocks the transcription of Hh target genes. On the contrary, in the presence of Hh ligand, Ptc releases the inhibitory effect exerted on Smo which is activated by PKA and CK1 phosphorylation on the C-terminal domain, and then bound by Cos 2 and $\mathrm{Fu}$. These processes culminate in the $\mathrm{Ci}$ activation, promoting Hh transcription. (B) The Hedgehog signaling pathway in vertebrates. When the pathway is turned off, PTCH prevents the accumulation of SMO in the primary cilium. SUFU restrains GLI transcription factors in the cytoplasm where PKA, CK $1 \alpha$, and GSK $3 \beta$ kinases promote their phosphorylation. This process attracts the $\mathrm{SCF}^{\beta \operatorname{TrCP}}$ E3 ligase that determines the processing of GLI2 and GLI3 $\left(\mathrm{GLI} 2 / 3^{\mathrm{R}}\right)$ in their repressor forms and the proteasome-mediated degradation of GLI1. In presence of HH ligand, PTCH inhibition is relieved. SMO is accumulated in the primary cilium and activated by GRK2 and CK1 $\alpha$ phosphorylation. GLI activator forms (GLIs ${ }^{\mathrm{A}}$ ) translocate into the nucleus and induce the transcription of $\mathrm{HH}$ target genes.

In mammals, three ligands belonging to the $\mathrm{HH}$ family are secreted: Desert hedgehog (DHH), Indian hedgehog $(\mathrm{IHH})$ and Sonic hedgehog $(\mathrm{SHH})$. The proteins, encoded by three paralogous mammalian genes, share high similarity in the affinity with $\mathrm{HH}$-binding proteins. $\mathrm{SHH}$ is mostly expressed in brain cells and implicated in central nervous system (CNS) development, while IHH modulates chondrogenesis, and DHH regulates spermatogenesis and nerve-Schwann cell interactions [7]. 
A peculiar characteristic of $\mathrm{HH}$ signal transduction is the role of the primary cilium. This organelle is a microtubule-based protrusion of the cell membrane that coordinates protein trafficking events, recruits and stabilizes a regulative dynamic network among the core of $\mathrm{HH}$ components [8].

The complexity of $\mathrm{HH}$ signaling in vertebrates is also provided by the GLI zinc-finger transcription factors, the final effectors of the pathway (Figure 1B). Three GLI members have been identified, GLI1, GLI2 and GLI3: GLI1 acts exclusively as activator, instead GLI2 and GLI3, which have an N-terminal repressor domain, can work either as repressors or activators [9]. The balance between activator and repressor forms is widely ruled by SUFU, an essential negative regulator that controls $\mathrm{HH}$ signaling through its direct interaction with GLI factors $[9,10]$.

When the HH pathway is off, phosphorylated GLI1 is recognized by the Skp1-Cullin1- $\beta \operatorname{TrCP}$ $\left(\mathrm{SCF}^{\beta \operatorname{TrCP}}\right)$ ubiquitin ligase complex and degraded by proteasome system, whereas GLI2 and GLI3 undergo a proteolytic process that converts them into cleaved transcriptional repressor forms. Otherwise, the binding of mature $\mathrm{HH}$ ligand to $\mathrm{PTCH}$ receptor releases the inhibition exerted on SMO, resulting in its activation and translocation into the cilium. These events lead to the nuclear localization of GLI activator forms where they induce the expression of HH-target genes, which include GLI1 itself, thus triggering a positive feedback loop that amplifies the signal [11,12].

The HH pathway output is tightly regulated at multiple levels by different post-translational modifications, such as phosphorylation and ubiquitylation [13-15]. The pattern of GLI phosphorylation triggered by the protein kinase A (PKA), the casein kinase 1 (CK1 $\alpha)$ and the glycogen synthase kinase 3 (GSK3 $\beta$ ) establishes multiple states of GLI activity and ultimately influences the $\mathrm{HH}$ transcriptional program [16]. The sequential phosphorylation of GLI proteins leads to the recruitment of the SCF ${ }^{\beta} \operatorname{TrCP}$, thus promoting GLI ubiquitylation and proteasome-mediated processing, as also described for its homolog Ci in Drosophila [17].

The ubiquitin-mediated processes of GLI factors are also triggered by other E3 ligases, such as the RING Cullin3-HIB/Roadkill/SPOP complex, the acetyltransferase/E3 ligase PCAF (P300/CBP-associated factor), and the HECT E3 ligase Itch. Importantly, Itch controls HH signaling by distinct routes: it mediates regulatory events on SUFU and proteasome degradation of GLI1 and PTCH1 by the interaction with the adaptor proteins $\beta$-arrestin2 and $\mathrm{Numb}$, respectively [18-25].

In the last years, post-translational modifications have also been described to control SMO activity. As GLIs, SMO is regulated, in response to $\mathrm{HH}$ stimuli, by PKA/CK1-mediated phosphorylation in Drosophila and GRK2/CK1 $\alpha$ in mammals, and downregulated by ubiquitin-mediated endocytosis and ubiquitin-dependent lysosome or proteasome degradation [26]. In Drosophila, Smo ubiquitylation and trafficking on cell surface is regulated by the HECT E3 ligases Smurf and Herc4, and the E3 ligase complex formed by Cullin4 and DNA-damage-binding protein 1 (DDB1), recruited by Smo through the $\beta$ subunit of trimeric $G$ protein $(G \beta)[27,28]$. Moreover, in mammals HERC4 has been described as tumor suppressor in non-small cell lung cancer (NSCLC) able to control SMO protein stability [29].

Given the essential role of $\mathrm{HH}$ signaling for a proper development, mutations in its key players cause congenital malformations [30]. An uncontrolled and permanent activity of the $\mathrm{HH}$ pathway is also associated to various human cancers such as basal cell carcinoma (BCC), medulloblastoma (MB), gliomas, pancreatic, colorectal, prostate, lung, and breast cancers (Figure 2) [31-33]. Indeed, aberrant $\mathrm{HH}$ activation involves and triggers pro-tumorigenic events, such as proliferation, survival, angiogenesis, migration and epithelial-mesenchymal transition (EMT) [34], thus affecting every step of carcinogenesis, from early development to metastatic progression [31,32]. 


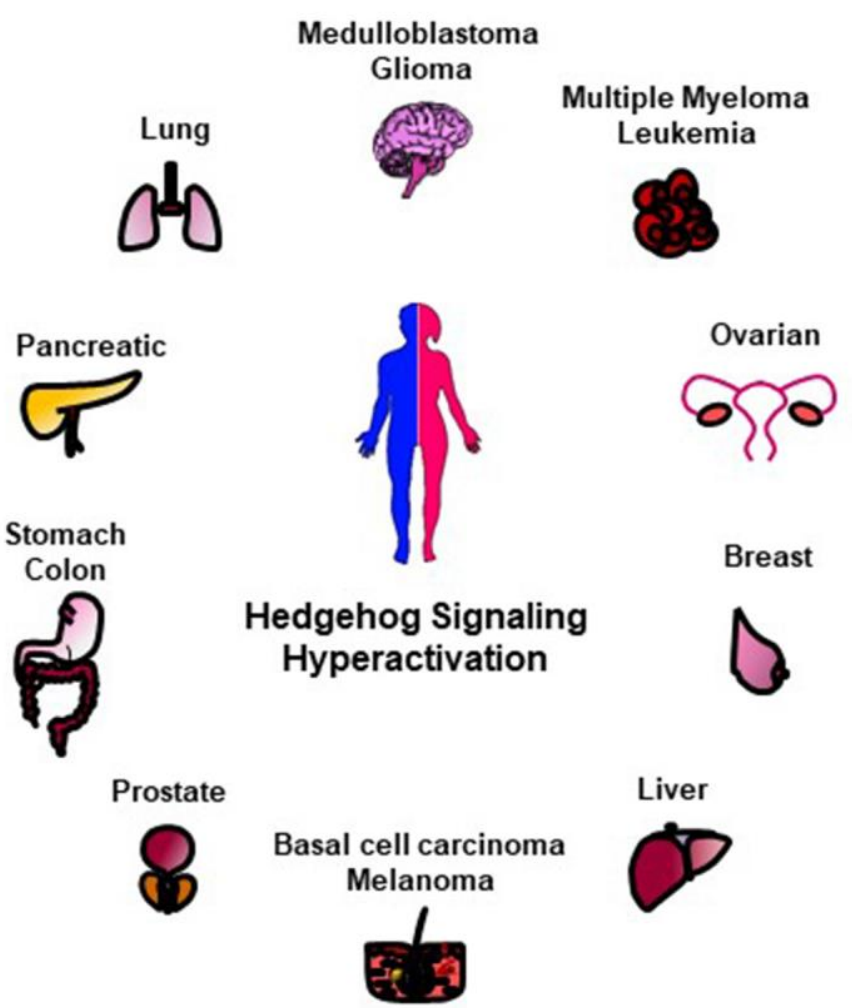

Figure 2. Schematic representation of $\mathrm{HH}$-related tumors. The hyperactivation of $\mathrm{HH}$ signaling is involved in the tumorigenesis of several human malignancies here reported.

Hyperactivation of $\mathrm{HH}$ signaling can occurs through either ligand-independent or ligand-dependent mechanisms. Tumorigenesis is ligand-independent when the pathway is constitutively activated in the absence of ligand via mutations in $\mathrm{HH}$ signaling components. Loss-of-function mutations in PTCH or SUFU or gain-of-function mutations in SMO, as well as GLI1 overexpression or GLI2 amplification have been identified in BCC, a common human skin cancer, and in MB, a highly malignant pediatric brain tumor [35-39]. Depending on the type of $\mathrm{HH}$ ligand release, two mechanisms of ligand-dependent pathway hyperactivation have been described in cancers, generating a tumor-stromal crosstalk [40]. Ligand-dependent autocrine/juxtacrine secretion occurs when the HH ligand is profusely released and caught by the same tumor cells, thus activating the pathway. Tumors that arise from this condition may display HH ligand overexpression or high levels of PTCH1 and GLI1 [41-43]. Alternatively, a paracrine secretion of HH ligand by tumor cells can induce the activation of the $\mathrm{HH}$ pathway in stromal cells of tumor microenvironment. As consequence, the stroma secretes paracrine growth signals to induce tumor growth [44]. For instance, in prostate cancer specimens, the expression of $\mathrm{HH}$ was detected in the tumor epithelium, while GLI1 expression was found in the tumor stroma cells, suggesting their paracrine crosstalk [45]. Moreover, this mechanism of $\mathrm{HH}$ signaling activation can work in a reverse paracrine manner in which cancer cells take the $\mathrm{HH}$ ligand released by stromal cells. For example, HH ligand released by bone marrow, nodal and splenic stroma can activate the $\mathrm{HH}$ pathway and maintain the survival of $\mathrm{B}$ and plasma cells in hematological malignancies [46]. Interestingly, HH-producing microenvironment is required for GLI activation in gliomas [47].

Of note, $\mathrm{HH}$ signaling also regulates the expression of the stemness genes Nanog and Oct4, thus participating in the formation or maintenance of cancer stem cells (CSCs) responsible of tumor initiation, relapse and drug resistance [48-50]. For all these reasons, the $\mathrm{HH}$ pathway is emerged as an attractive druggable target for anti-cancer therapy. A various number of SMO antagonists, able to block the pathway at upstream level, have been identified and patented. Some of them, vismodegib and sonidegib, and recently glasdegib, have been approved by the Food and Drug Administration (FDA) 
for the treatment of BCC and Acute Myeloid Leukemia (AML), respectively [34]. Many others, such as GANT61 and GlaB, have been designed targeting GLI1, the downstream effector of HH signaling, and have shown efficacy in preclinical study [34,51,52]. The major issue in employment of HH-inhibitors is the recurrence of drug-resistance mutations or alternative mechanisms of activation. Consequently, multi-target therapy is emerging as a promising strategy for the treatment of $\mathrm{HH}$-dependent cancers. The best approach envisioned so far is the development of further inhibitors, or the identification of additional regulators of the $\mathrm{HH}$ pathway that could be targeted in tumorigenesis.

\section{Ubiquitylation Process}

Ubiquitylation dictates the fate and function of most cellular proteins increasing the complexity of the proteome. This modification is a dynamic and tightly regulated post-translational event with many distinct outcomes affecting protein stability, localization, interactions, and activity.

Ubiquitin $(\mathrm{Ub})$ is a small globular protein consisting of 76 amino acids encoded in mammals by four different genes (UBB, UBC, RPS27, and UBA52) that ensure high cellular Ub levels [53]. Ubiquitylation is a multi-step process orchestrated by an enzymatic cascade that relies on $\mathrm{Ub}$ and three different enzymes: Ub-activating (E1), Ub-conjugating (E2), and Ub-ligating (E3) [54]. During the catalytic reactions, $\mathrm{Ub}$ is activated in an ATP-dependent way by an E1 enzyme, subsequently transferred to the active cysteine (Cys) residue of an E2 enzyme via a trans-(thio) esterification reaction, and finally attached with an isopeptide bond to a substrate by an E3 enzyme (Figure 3A). In humans, two E1s, around $30 \mathrm{E} 2 \mathrm{~s}$ and over $600 \mathrm{E} 3 \mathrm{~s}$ have been identified $[55,56]$. The latter are the major determinants and provide specificity for substrate recognition. Based on their functional domains and on the mechanism of catalysis, E3s are divided into three main families: the Really Interesting New Gene (RING), the Homologous to the E6-associated protein Carboxyl-Terminus (HECT) types, and RING-between-RING (RBR), which can be considered a RING-HECT hybrid [57,58]. Each class of E3 ligases can create Ub linkages of different length and architecture. The transfer of the $\mathrm{Ub}$ moiety to substrate occurs through the formation of the covalent bond between $\alpha$-carboxyl group of the terminal glycine (Gly) residue of $\mathrm{Ub}$ and, commonly, $\varepsilon$-amino group of an internal lysine (Lys) residue of the substrate. Of note, for a subset of substrates the attachment of $\mathrm{Ub}$ may interest their N-terminal residue, a process known as N-terminal ubiquitylation [59], or serine and threonine residues, further expanding the complexity and the biological relevance of this process. In this regard, $\mathrm{Ub}$ modifications of a target protein occur in various forms: attachment of a single $\mathrm{Ub}$ moiety on a single substrate residue (monoubiquitylation), a single $\mathrm{Ub}$ on multiple residues (multi-ubiquitylation), or additional $\mathrm{Ub}$ molecules to initial $\mathrm{Ub}$ yielding an ubiquitin chain (poly-ubiquitylation). Typically, mono- and multiubiquitylation regulate endocytosis, signal transduction, DNA repair, and often result in changes in the cellular localization and protein activity [60-62]. By contrast, polyubiquitylation is the most abundant modification that controls protein homeostasis. Indeed, the polyubiquitylated target substrates are recognized by the $26 \mathrm{~S}$ proteasome, a multiprotein complex, that degrades the proteins into small peptides and releases the $\mathrm{Ub}$ for cyclic utilization [63]. Besides regulating protein degradation, polyubiquitylation brings different functional consequences depending on $\mathrm{Ub}$ chain linkage-type [64]. Ub has seven Lys residues (K6, K11, K27, K29, K33, K48, and K63) that may serve as polyubiquitylation points. Depending upon the Lys used, length of the chains and linkage type, distinctive forms of $\mathrm{Ub}$ chains may be achieved to drive the fate of target proteins [65]. Lys48-linkage targets protein for proteasome-dependent degradation, whereas Lys63-linkage is associated to regulative processes, including trafficking, protein localization, protein-protein interaction; the biological significance of other $\mathrm{Ub}$ modifications is still largely unclear [66]. Further complexity is provided by $\mathrm{Ub}$ modifications (i.e., phosphorylation, acetylation, sumoylation) and by the linkage of Ub to other Ub-like proteins (i.e., NEDD8, SUMO), creating a multitude of distinct signals. The combination of all these parameters has been referred as the "Ub code" [65]. The Ub code governs the fate of the targeted substrates by modulating their interactions with many other proteins that incorporate Ub-binding domains and determine their accessibility to deubiquitylating enzymes (DUBs), a family of protease conserved from yeast to humans [67]. 


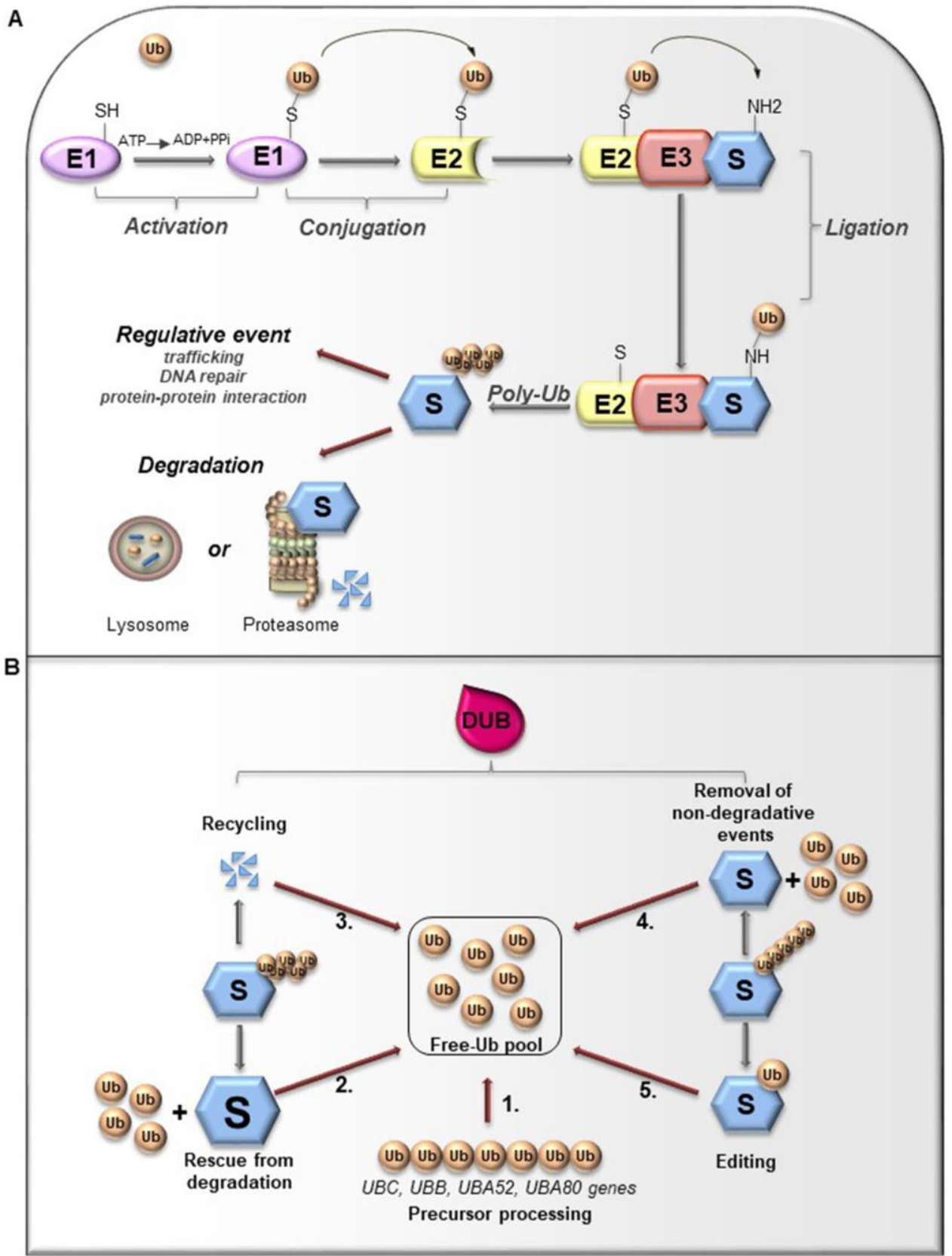

Figure 3. (A). Ubiquitylation processes. Ubiquitylation is a multi-step process that involves three enzymes: E1 (Ub-activating enzyme), E2 (Ub-conjugating enzyme) and E3 (Ub-ligase). Initially, Ub is linked to E1 through a high energy thioester bond. After, Ub activated by E1 is conjugated to a sulfhydryl group on E2 enzyme. Finally, E3 ligase specifically catalyzes the transfer of Ub from E2 to a Lys residue on a substrate protein. The formation of a poly-ubiquitin (poly-Ub) chain can lead the substrate toward a degradative or regulative pathway. (B). Deubiquitylation and DUBs function. Ubiquitylation can be reversed by deubiquitylating enzymes (DUBs) that hydrolyze the isopeptide or peptide bond, leading to $\mathrm{Ub}$ deconjugation from the ubiquitylated protein. DUBs have many functions. 1. Precursor processing: $\mathrm{Ub}$ is encoded by four genes and translated as a linear fusion protein consisting of multiple Ub copies, which require the cleavage by DUBs in order to generate free single $\mathrm{Ub}$; 2 . Rescue from degradation: DUBs can rescue protein from proteasomal or lysosome degradation; 3. Recycling: DUBs maintain $\mathrm{Ub}$ homeostasis preventing its degradation following substrate proteolysis; 4 . Removal of non-degradative events: DUBs can remove Ub chains from substrates that are not committed to degradation; 5. Editing: DUBs can also affect the fate of ubiquitylated substrates by cleaving inter-Ub chains (switching from degradative to non-degradative ubiquitylation). 


\section{Deubiquitylating Enzymes: Functions and Classification}

Like other important post-translational modifications, ubiquitylation is a dynamic and reversible process counteracted by DUBs activity [65]. DUBs are proteases that hydrolyze isopeptide or peptide bond removing $\mathrm{Ub}$ conjugates from substrates and disassembling anchored $\mathrm{Ub}$ chains (Figure 3B) $[65,68]$. DUBs may remove $\mathrm{Ub}$ moieties from the distal end or through the cleavage within chains in two distinct ways: i) via direct interaction with specific substrates; ii) through selective recognition for particular $\mathrm{Ub}$ chain architecture. Both chain length and linkage type may drive the choice of the target proteins. Importantly, linkage selectivity may occur within the catalytic domain or through the cooperation with Ub-binding domains within DUBs or their interaction partners [68].

Given their crucial role in opposing E3 ligases function, DUBs control protein homeostasis and activities, and are implicated in the regulation of various physiological and pathological processes, such as development, metabolism, immune response and tumorigenesis.

Currently, 99 cellular DUBs have been identified and are classified into six main families depending on distinct catalytic domains: the largest group ubiquitin-specific proteases (USPs), ubiquitin C-terminal hydrolases (UCHs), ovarian tumor proteases (OTUs), JAD/PAD/MPN-domain containing metalloenzymes (JAMMs), Machado-Joseph disease domain proteases (MJDs or Josephins) and motif interacting with Ub-containing novel DUB family (MINDYs) $[69,70]$. Unlike of the JAMM family, classified as a zinc-dependent metalloproteinase, the other DUBs classes are cysteine proteases. Available data indicate that each family may display linkage or substrate preferences. For instance, OTU family exhibits linkage type specificity, whereas USP group members show differences in catalytic rate constants $[68,71,72]$. Studies aimed at defining the abundance of individual DUBs suggest that those with constitutive functions show high copy number, while DUBs with peculiar roles are the rarer forms [70]. Different approaches used to determine the intracellular localization of the DUBs allowed highlighting that subsets of these proteases show particular association with subcellular compartments. Although many DUBs are nuclear, several USP members localize to defined structure including plasma membrane, microtubules, endosome, and endoplasmic reticulum (ER) [73].

To date, a growing body of evidence indicated that DUBs can act as oncogenes or tumor suppressors emerging as a promising class of therapeutic targets. For these reasons, many efforts are devoted to the development of highly selective DUBs inhibitors for anti-cancer therapies.

\section{Oncogenic DUBs Involved in the Regulation of the HH Pathway}

\subsection{DUBs Acting on SMO}

$\mathrm{SMO}$ is the main upstream signal transducer of the HH pathway in both insects and vertebrates. SMO is classified as an atypical G protein-coupled receptor (GPCR), since it possesses stereotypical GPCR functional domains: seven transmembrane domains (TM), an intracellular C-terminal tail, an amino-terminal cysteine rich domain (CRD), three extracellular and three intracellular loops (ECL and ICL) $[74,75]$.

The molecular mechanisms that induce SMO activity in response to the activation of the $\mathrm{HH}$ pathway represent a crucial question in the understanding of $\mathrm{HH}$ signal transduction. In Drosophila, activated Smo accumulates in the plasma membrane [76,77], while in vertebrates it translocates into the primary cilium, a small protruding organelle in which all the key components of $\mathrm{HH}$ signaling are enriched [78,79]. Post-translational modifications regulate Smo activity. At present, the positive role of phosphorylation on Smo subcellular trafficking and activation is well established: in Drosophila protein kinase A (PKA) and casein kinase 1 (CK1)-mediated phosphorylation promotes Smo cell surface localization [80-83], whereas in vertebrates GRK2 and CK1 $\alpha$-dependent phosphorylation of SMO C-tail has been found to be pivotal for its ciliary accumulation [83]. In the last years, the role of ubiquitylation as negative modulator of Smo, due to the involvement in its endocytosis, trafficking and degradation has increasingly emerged $[26,84]$. 


\subsubsection{USP8}

Ubiquitin-specific protease 8 (USP8) is a multi-domain deubiquitylating enzyme with pleiotropic functions. Besides its canonical role in protein trafficking and receptor tyrosine kinase degradation, USP8 controls other biological processes, such as endosomal sorting, mitochondrial quality control, ciliogenesis and apoptosis [85]. Indeed USP8 was found to deubiquitylate the E3-ubiquitin ligase Parkin, involved in autophagy of dysfunctional mitochondria, the HIF1 $\alpha$ protein, important for endosome trafficking-mediated ciliogenesis, and c-FLIP a master anti-apoptotic player [85]. Recently, the involvement of USP8 in the regulation of Hh signaling, through the stabilization of Smo, has been described.

Two independent studies have demonstrated that the absence of Hh ligand induces both the polyand monoubiquitylation of Smo, leading to its endocytosis and degradation both by the lysosome- and proteasome-mediated pathway, in order to keep Hh signaling off $[26,84]$. Conversely, upon ligand stimulation, Smo is deubiquitylated and hence accumulated on the cell surface, where it becomes activated [84]. By using an in vivo RNAi screen that targeted Drosophila DUBs, Xia and colleagues identified USP8 as a deubiquitylase that prevents Smo ubiquitylation and is required for Hh-induced cell surface accumulation of Smo, thus increasing Hh signaling activity [84].

A

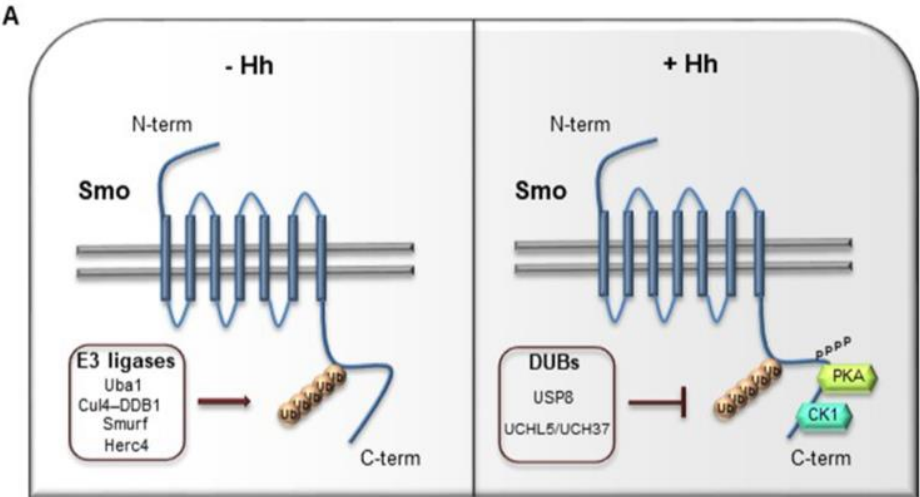

B

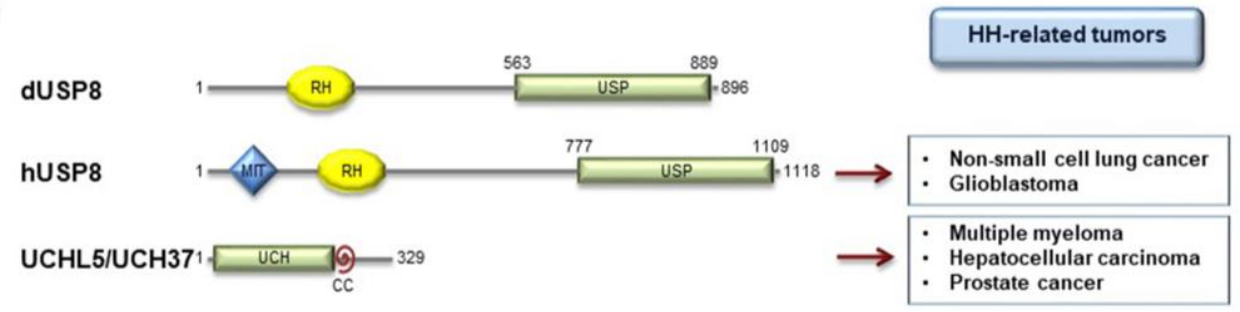

Figure 4. (A) E3-ubiquitin ligases and DUBs involved in Smo regulation. In Drosophila, when the Hh pathway is OFF, Smo is ubiquitylated by multiple E3 ligases (Uba1, Cul4-DDb1, Smurf, Herc4) that induce Smo lysosome or proteasome degradation. Conversely, when Hh signaling is activated, Smo is deubiquitylated by USP8 or UCHL5/UCH37 and then accumulated on cell surface, where it is active. This event is induced by PKA- and CK1-phosphorylation at the C-terminal region of Smo. (B) Structure of Drosophila dUSP8, human hUSP8, and UCHL5/UCH37. The boxes on the right indicate the main HH-related tumors in which USP8 and UCHL5/UCH37 are involved. USP: ubiquitin specific protease domain; MIT: microtubule interacting and trafficking molecule domain; RH: Rhodanese-like domain; CC: coiled coil domain.

Similar results have been obtained in NIH3T3 cells, suggesting a conserved mechanism that controls SMO in mammals. Moreover, the authors sustain a link between phosphorylation and ubiquitylation in controlling Smo activity. Indeed, Hh promotes the interaction of USP8 with Smo aa625-753, the residues phosphorylated by PKA and CK1, showing that phosphorylation of Smo induces the formation of Smo/USP8 complex and amplifies Hh stimulation (Figure 4A,B). Parallelly, 
the sumoylation of Smo at K851 induced by Hh, recruits USP8 to inhibit Smo ubiquitylation and degradation, leading to its cell surface trafficking and amplifying the Hh pathway activity, both in Drosophila and mammals [86]. These data stand USP8 as a positive regulator in the $\mathrm{HH}$ pathway, able to prevent SMO localization to early endosomes, promoting its stability [84].

\subsubsection{UCHL5/UCH37}

A similar role to USP8 has been described by Zhou et al. for the deubiquitylase UCHL5 able to increase the protein stability and the cell membrane accumulation of Smo [87]. UCHL5 (also known as UCH37 in mammals) is a deubiquitylase involved in the regulation of several substrates (i.e., type I TGF- $\beta$ receptor, E2 promoter binding factor 1$)[88,89]$ and is formed by an $\mathrm{N}$-terminal UCH and a C-terminal extension domains (Figure 4B) [90]. In Drosophila, the UCH region of UCHL5 binds Smo C-tail [87]. Through its C-terminal fragment, UCHL5 recruits Rpn3, a proteasome subunit that increases UCHL 5 deubiquitylating activity and forms a trimetric complex with Smo, thus reducing its ubiquitylation. Moreover, UCHL5 inhibits the interaction of Smo with the hepatocyte growth factor-regulated tyrosine kinase substrate (Hrs), known to promote Smo ubiquitylation [91]. Interestingly, ubiquitylation assays performed in knockdown conditions of UCHL5 and USP8 demonstrated that this two DUBs cooperate to deubiquitylate and stabilize Smo [87]. The activation of the Hh pathway does not affect the expression levels of UCHL5, but increases the affinity between UCHL5 and Smo, stabilizing the receptor with its consequent localization at the cell membrane [87]. Importantly, this mechanism is conserved in mammals through its homolog UCH37 [87]. Many evidence show that UCH37 is upregulated in a wide spectrum of tumors, suggesting its potential oncogenic role in tumorigenesis [92-94].

Although the negative role of Smo ubiquitylation in the control of Hh activity is well established, only recently the E3 ligases involved in this process have been identified in Drosophila, and include Uba1, Cul4-DDB1, Smurf, and Herc4 (Figure 4A) [26-28,84,95,96]. In particular, recent findings displayed that the HECT E3 ligase Herc4 binds Smo and mediates its mono- and polyubiquitylation at multiple Lys residues, thus promoting its lysosome and proteasome degradation. The interaction between Smo and Herc4 is inhibited by Hh that prevents Herc4-mediated Smo ubiquitylation in a manner independent of PKA-primed phosphorylation [95]. Importantly, Herc4 interacts with USP8 and UCHL5 and their overexpression almost abolishes Herc4-mediated Smo ubiquitylation, by blocking the association between Herc4 and Smo [95]. In mammals, HERC4 binds SMO and induces its degradation. In human NSCLC, HERC4 knockdown activates HH signaling and promotes NSCLC cell proliferation thus standing as a tumor suppressor [29].

Multiple E3 ligases and DUBs are involved in the fine regulation of SMO stability and trafficking, and the perturbation of their function could alter the $\mathrm{HH}$ pathway activity. In particular, given the positive role of DUBs in controlling $\mathrm{HH}$ signaling, they emerged as a potential drug target for HH-related tumors.

\subsection{DUBs Acting on GLI Factors}

GLI zinc finger transcription factors are the main effectors of $\mathrm{HH}$ signaling. Both SMO-dependent and independent $\mathrm{HH}$ pathway activation culminate with the nuclear translocation of GLIs, promoting the expression of $\mathrm{HH}$ target genes. GLIs function is widely ruled by post-translational modifications. In particular, GLI ubiquitylation is orchestrated by several E3 ligases belonging both to the RING (such as SCF ${ }^{\beta T r C P}$ and Cullin3-HIB/Roadkill/SPOP $[17,97,98]$ ) and the HECT (Itch) families $[24,99]$, and the non-canonical E3 ligase PCAF $[25,100]$. This modification leads to proteolytic cleavage of GLI2 and GLI3 factors $[97,98]$ or massive degradation especially for GLI1 protein $[17,23,24]$.

\subsubsection{USP7}

Ubiquitin-specific protease 7 (USP7, also called Herpes virus-associated protease, HAUSP) is the first identified deubiquitylase isolated as a partner of the herpesvirus protein [101]. USP7 is a 
cysteine peptidase primarily located in the nucleus where it controls the stability of multiple proteins involved in the Zhou and colleagues described USP7 as positive modulator of HH signaling in flies and vertebrates. Indeed, Usp7 in Drosophila and its homolog HAUSP in mammals antagonize multiple E3 regulation of DNA damage response, transcription, epigenetic control of gene expression, immune response, and viral infection. Indeed, among the many substrates of USP7 are included the tumor suppressor proteins p53 and PTEN, the oncoproteins C-Myc and N-Myc, the transcription factors Foxp3 and FOXO family members, the DNA methyltransferase 1 (DNMT1), the checkpoint kinase 1 (CHK1) and viral proteins, such as EBNA1 and ICP0 [102].

In mouse Usp7 knockout is lethal $[103,104]$, while in human its mutations and deletions have been recently identified in children suffering from neurodevelopmental disorders [105]. ligases function to maintain the $\mathrm{HH}$ pathway activity [106]. In particular, upon Hh treatment Usp7 interacts with Ci through multiple P/AxxS motifs and increases its protein stability [106]. Usp7 localizes in both cytoplasm and nucleus and counteracts respectively SCF $^{\text {Slimb }}$ and Hib-Cul3-mediated Ci degradation (Figure 5A) [106].
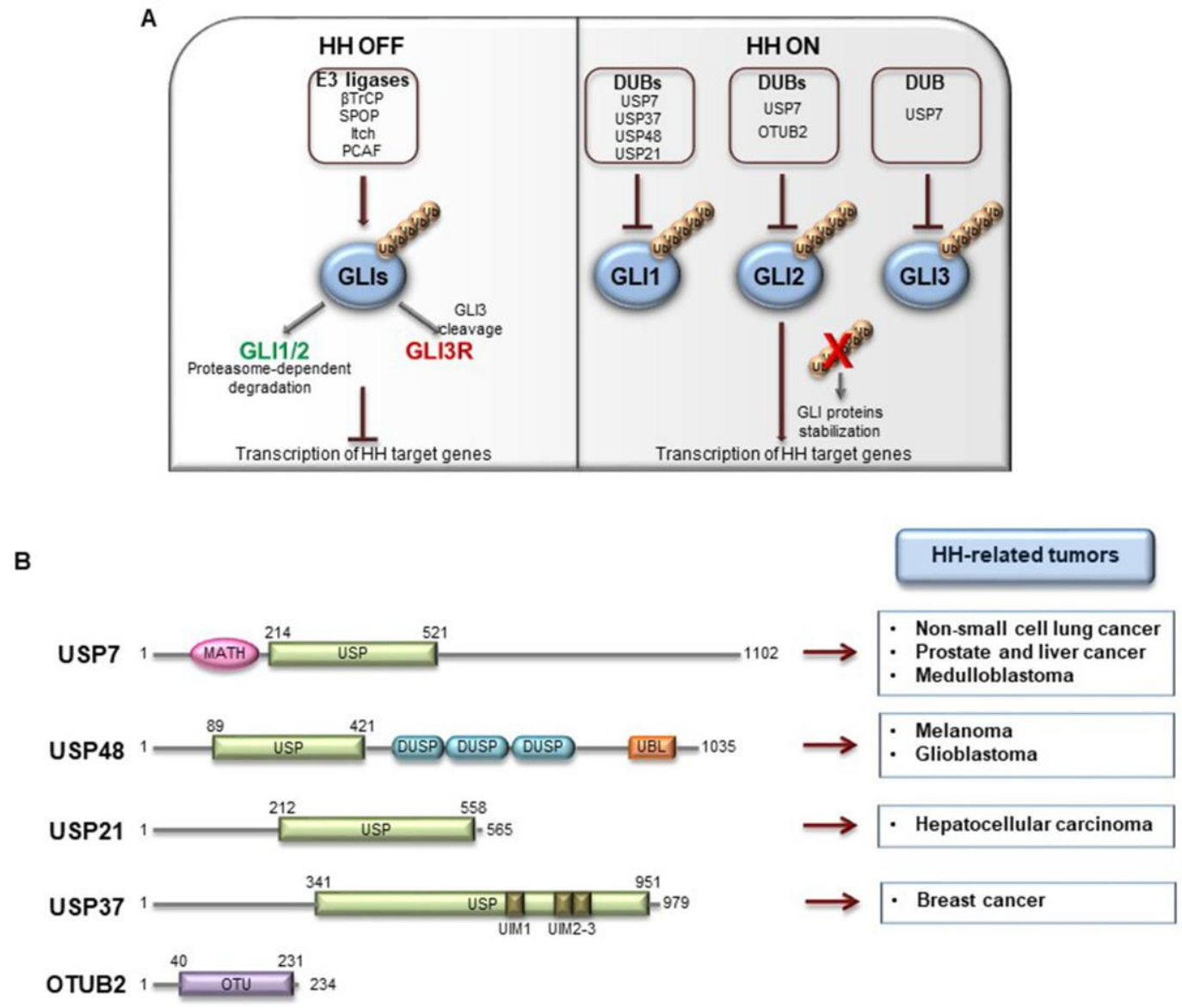

Figure 5. (A) E3-ubiquitin ligases and DUBs involved in GLI proteins regulation. In mammals, all GLI factors undergo ubiquitylation processing by different E3-ubiquitin ligase ( $\beta \operatorname{TrCP}$, SPOP, Itch, PCAF). When the pathway is OFF, $\mathrm{SCF}^{\beta \mathrm{TrCP}} \mathrm{E} 3$ ligase promotes the proteasome-dependent degradation of GLI1 and GLI2, and the proteolytic cleavage of GLI3 and to lesser extent GLI2 into the repressor forms. This modification blocks the transcriptional activity of GLIs. Ubiquitylation events are counteracted by the activity of DUBs (USP7, USP37, USP48, USP21, OTUB2) which remove Ub moieties from GLI factors. GLI proteins are then stabilized and can exert their activity promoting the expression of $\mathrm{HH}$ target genes. (B) Structure of human DUBs acting on GLI proteins. The boxes on the right indicate the main HH-related tumors in which these DUBs are involved. USP: ubiquitin specific protease domain; DUSP: dual-specificity phosphatase domain; UBL: ubiquitin-like domain; UIM: ubiquitin-interacting motif; OTU: ovarian tumour domain; MATH: meprin and TRAF homology domain. 
Similarly, USP7 binds all GLI factors in mammals, and these interactions are favored by HH and hindered by SUFU [106]. USP7 stands as positive regulator of HH signaling that stabilizes GLIs protein levels by antagonizing either the Itch-dependent degradation of GLI1 [24,99], and the SPOP/CUL3-dependent degradation of GLI2/GLI3 (Figure 5A) [107,108].

Usp7 knockout in mouse cause embryonic lethality at embryonic days (E) 6.5-7.5 [103], while in human USP7 shows an oncogenic role in neoplastic diseases such as NSCLC, human prostate and liver cancers $[109,110]$. Zhan and collaborators also investigated the effects of USP7 modulation on human MB, the most common pediatric tumor of the cerebellum [111]. About $30 \%$ of all MBs arises from $\mathrm{HH}$ signaling aberrant activation (HH-MBs) [112]. USP7 depletion inhibits the proliferation rate, the migration capability and the invasiveness of human HH-MB Daoy cells due to the decrease of GLIs protein levels and of $\mathrm{HH}$ target genes transcription [113]. The treatment of Daoy cells with the USP7 inhibitors, P5091 and P22077, blocks their proliferation and metastasis [113] standing USP7 as potential druggable target in SHH-MBs.

\subsubsection{USP48}

Ubiquitin-specific protease 48 (USP48) contains an ubiquitin C-terminal hydrolase (UCH) domain, required for its catalytic activity, and an ubiquitin-specific proteases (DUSP) domain mostly involved in protein-protein interaction (Figure 5B) [114]. Several substrates of USP48 have been recently identified, such as the tumor necrosis factor receptor-associated factor 2 (TRAF2) related to JNK pathway, the histone $\mathrm{H} 2 \mathrm{~A}$ and RelA, a member of the avian reticuloendotheliosis/NF- $\mathrm{kB}$ transcription factors family [115-117]. Moreover USP48 is a novel binding partner of Mdm2, promoting its stability with a deubiquitinase activity-independent mechanism [118]. USP48 is expressed in almost all human tissues [119] and is upregulated in malignant melanoma [120]. Zhou and co-authors recently highlighted the USP48 involvement in $\mathrm{HH}$ signaling regulation and its role as promoter of glioblastoma cell proliferation and tumorigenesis [121]. USP48 and GLI1 co-localize in the nucleus, interacting through the N-terminal sequence of GLI1 and the C-terminal DUSP domain of USP48 [121]. This interaction protects GLI1 from proteasome-dependent degradation thus increasing its protein stability (Figure 5A). The specific function of USP48 on GLI1 promotes the proliferation and the colony formation of glioma cells in vitro. Moreover, its depletion abrogates the tumor formation and extends the survival rate of orthotopic glioblastoma mouse models in vivo [121]. Zhou and colleagues sustained a positive feedback loop by which HH signaling activates USP48 through the binding of GLI1 to Usp 48 promoter. Of note, USP48 and GLI1 expression levels directly correlate in human glioblastoma specimens, and they are linked to tumor malignancy grade. This evidence underlies the relevance of USP48-GLI1 regulatory axis for glioma cell proliferation and glioblastoma tumorigenesis [121].

\subsubsection{USP21}

The ubiquitin specific peptidase 21 (USP21) is the only centrosome and microtubule-associated DUB and localizes at the basal bodies in ciliated cells [73]. USP21 activity leads to the stabilization of many substrates, such as the pluripotency factor Nanog and the Mitogen-activated protein kinase kinase 2 (MEK2), a member of MAPK signaling cascade, thus sustaining stemness and cell proliferation, respectively [122,123]. Heride et al. described that USP21 positively regulates $\mathrm{HH}$ signaling either acting on the formation of primary cilium or altering GLI1 transcription activity [124], without excluding the interplay between these two mechanisms (Figure 5A). The authors demonstrated that USP21 and GLI1 form a complex and, together with PKA, colocalize at the centrosome in U2OS cells. Indeed, USP21 recruits GLI1 close to active PKA thus stimulating GLI1 phosphorylation [124,125]. Both depletion and overexpression of USP21 can hinder HH signaling, highlighting its regulatory role in the modulation of this pathway [124]. 


\subsubsection{USP37}

Ubiquitin specific peptidase 37 (USP37) mainly localizes in the cytoplasm [126] and it has been initially described as a potent regulator of cell cycle at the G1/S transition, due to its ability to stabilize cyclin A. [127,128]. Moreover, USP37 is involved in the regulation of the stemness marker Nanog, of the EMT transcription factor Snail and of the oncoprotein C-Myc [129,130]. Qin et al., described the interplay among USP37 expression, the HH pathway, and EMT in breast cancer stem cells (BCSCs) [131]. In particular, they observed that genetic depletion of USP37 in these cells induces the reduction of $\mathrm{HH}$ key components at protein level (such as SMO and GLI1) as well as of stem cell markers (i.e., ALDH1 and OCT4) [131]. In contrast, the activation of $\mathrm{HH}$ signaling induced by the agonist purmorphamine (PM) results in enhanced USP37 gene expression that in turn stabilizes GLI1 (Figure 5A), and impacts on EMT in BCSBs [131]. These findings confirm the role of $\mathrm{HH}$ signaling in the maintenance of stem cells and EMT $[132,133]$ and the implication of DUBs deregulations on these oncogenic processes $[134,135]$. Indeed, USP37 downregulation attenuates cell invasion and EMT markers expression by suppressing the HH pathway [131]. Moreover, in vivo xenograft mouse model of breast cancer showed that tumors resulting from USP37 silenced cells are more sensitive to cisplatin, and have impaired $\mathrm{HH}$ target and stemness genes expression, together with lower proliferation ability compared to control group [131]. Overall these data indicate the relevance of USP37 in the regulation of breast cancer progression via the activation of the $\mathrm{HH}$ pathway.

\subsubsection{OTUB2}

Ubiquitin thioesterase otubain-2 (OTUB2) is a deubiquitylating cysteine protease belonging to the ovarian tumor (OTU) superfamily of DUBs. Virus can encode DUBs to alter Ub-mediated host cell processes $[136,137]$, and OTUB2 has been reported for its inhibitory activity on virus-triggered signaling through the deubiquitylation of TRAF3 and TRAF6 [138]. Further, OTUB2 affects DNA damage-dependent ubiquitylation, by protecting the polycomb molecule L3MBTL1 from RNF8-dependent degradation in an early phase of the DNA double-strand response (DDR) [139]. Recently, Li and co-workers described a new role for OTUB2 in the regulation of GLI2 stability (Figure 5A) [140]. In particular, the authors demonstrated the interaction between the two proteins and elucidated their interplay. The over-expression of OTUB2, but not of its catalytically inactive mutant C51A, protects GLI2 from proteasome-dependent degradation thus stabilizing and extending its half-life in U2OS cells [140]. Since $\mathrm{HH}$ signaling plays a relevant role in osteogenic differentiation during embryogenesis [141], Li et al. investigated the effects of OTUB2 genetic depletion in mesenchymal stem cells (MSCs). They observed that HH stimulation promotes the expression of key drivers of osteoblast differentiation and bone formation, an effect that is inhibited in OTUB2 knockdown condition. These findings outline OTUB2 as an agonist of HH signaling demonstrating its ability to stabilize GLI2 protein levels [140].

\section{HH-Related DUBs: Inhibitors and Therapeutic Applications}

Since the relevant role of DUBs in tumorigenesis, in the last decade many efforts have been devoted to the identification of selective DUBs inhibitors, demonstrating their therapeutic potential as anti-cancer agents [142-144]. DUBs that regulate key components of the $\mathrm{HH}$ pathway, such as USP7, USP8 and UCHL5/UCH37, are promising targets for the treatment of HH-dependent tumors. Their specific inhibitors with related chemical structures are summarized in Tables 1 and 2, respectively.

USP7 is one of the most studied and best characterized DUB for its implication in different human diseases and in a wide spectrum of human cancers [145]. The first USP7 inhibitor was HBX 41,108, a cyanindenopyzazine derivative. HBX 41,108 acts on USP7 [146] through an uncompetitive reversible mechanism, binding this DUB after the formation of the enzyme/substrate complex. Although this molecule has shown selectivity towards USP7 in HCT116 human colon cancer cells, its weak activity against other related proteases limits the use for further pre-clinical studies [146]. 
Few years later, the same research team identified structurally distinct USP7 antagonists; among them, HBX 19,818 exhibits an excellent selectivity for this DUB [147]. Reverdy and colleagues demonstrated that HBX 19,818 covalently binds the Cys223 located in the USP7 active site impairing cell proliferation and promoting apoptosis and cell cycle arrest in HCT116 cells. Of note, the viability of three cancer cell lines with different $p 53$ status is equally impaired by HBX 19,818 treatment, strongly suggesting that p53, one of the major USP7 target, is not required for the cellular response to USP7 inhibition. These findings suggest the existence of other USP7 substrates important for the proliferation of colon cancer cells [147]. To date, HBX 19,818 antitumor activity in vivo has not been yet described.

Subsequently, P5091 a trisubstituted thiophene, and its analog P22077 ((1-(5-((2,4-difluorophenyl)thio)-4-nitrothiophen-2-yl)ethanone)) have been identified as new USP7 inhibitors [148-150]. Although P22077 showed a cross-reactive effect against USP47, it has been used as USP7 antagonist in pre-clinical studies for neuroblastoma treatment. This compound significantly impairs tumor growth both in vitro and in vivo by inducing p53-mediated apoptosis or suppressing MYCN activity in MYCN-amplified neuroblastoma [151,152]. Interestingly, P22077 efficacy has been reported to suppress NSCLC and hepatocellular carcinoma tumor growth [153,154].

P5091 is one of the most well studied first-generation USP7 inhibitors, whose structure has been used as scaffold for chemistry optimization to develop new antagonists [150,155]. P5091 shows potent selective activity against USP7, inhibiting its ability to cleave high molecular weight poly-Ub chains in a dose-dependent manner. Chauhan and colleagues provided pre-clinical data on the anti-cancer efficacy of P5091 in multiple myeloma xenograft models. Interestingly, P5091 treatment impairs tumor growth by inducing apoptosis also in cells resistant to conventional and bortezomib therapies. All these evidence strongly support the clinical investigation of USP7 inhibitors, alone or in combination, as a valid therapeutic strategy for the treatment of multiple myeloma [150]. In addition, the potential therapeutic application of P5091 has also been reported for the treatment of various malignancies (Table 1) [156-162]. Notably, Zhan and colleagues showed that both P22077 and P5091 block proliferation and migration of MB cells, by reducing GLI proteins levels and inhibiting $\mathrm{HH}$ signaling [113].

Following advances in understanding the crystal structures of USP7, USP7-ligand complexes and its functional domains, several non-covalently binding USP7 inhibitors have been identified, including the 4-hydroxypiperidines XL188 [163,164], FT671 and compound 4 [165,166], the 2-aminopyridine GNE6640, GNE776 and the thiazole derivatives C7 and C19 $[167,168]$. Although these molecules show good potency and selectivity against USP7, further in vivo studies will be required to evaluate their therapeutic relevance in cancer treatment.

Noteworthy, USP7 inhibitors have also been identified from natural sources, such as spongiacidin C, a pyrrole alkaloid obtained from the marine sponge Stylissa massa [169]. Despite biochemical assays show a good selectivity for USP7 for these compounds, their efficacy in cells remains to be determined.

Finally, in the last year, two new USP7 antagonists have been identified. XL177A, an analogue of XL188, is a small molecule that irreversibly inhibits USP7 with sub-nanomolar potency and selectivity, and whose effectiveness seems to be associated with $p 53$ mutational status in multiple cancer lineages [170]. On the contrary, compound $\mathbf{4 1}$ is a reversible, highly potent, selective, and orally bioavailable USP7 inhibitor. In in vivo xenograft models of multiple myeloma, this molecule impairs the tumor growth of both p53 wild-type and mutant tumor cell lines, confirming that USP7 inhibition can suppress tumor growth affecting different pathways [171].

Currently only two molecules have been described as specific USP8 antagonists due to its pleiotropic function [85]. Colombo and colleagues identified the compound 9-ethyloxyimino-9H-indeno [1,2-b]pyrazine-2,3-dicarbonitrile as the first specific USP8 inhibitor [172]. Subsequently, the effectiveness of this molecule has been reported to markedly decrease the in vitro and in vivo tumor growth of both gefitinib-sensitive and -resistant NSCLC cells [173]. 
The second USP8 inhibitor, Ubv.8.2, is an engineered ubiquitin variant identified to be a highly specific and potent inhibitor of this enzyme, showing the ability to occlude its Ub-binding site [174]. The only evidence of a potential anti-cancer activity for this molecule has been reported by MacLeod and co-workers, who demonstrated that the lentiviral expression of Ubv.8.2 leads to cell viability reduction in glioblastoma stem cell lines [175].

The potential application of DUBs inhibitors for the treatment of HH-related tumors includes also the exploitation of small molecules specific for those DUBs associated with proteasome, such as UCHL5 and USP14 [176]. These enzymes broadly act on substrates addressed to degradation machinery and represent the most investigated druggable DUBs. Indeed, their inhibition might have considerable effects on tumor cells, resulting in a less toxic strategy than targeting directly the proteasome complex [142].

Most of the UCHL5 inhibitors are also able to block the activity of USP14, known to modulate the HH pathway by controlling ciliogenesis [177]. Among the UCHL5/USP14 inhibitors identified so far, b-AP15 (3,5-bis[(4-nitrophenyl)methylidene]-1-prop-2-enoylpiperidin-4-one) has been widely used for pre-clinical studies, exhibiting anti-cancer activity in both in vitro and in vivo models of different tumor types [178-189]. VLX1570, a derivative of b-AP15 [190], has been tested at pre-clinical level for the treatment of endometrial cancer, Ewing's sarcoma and acute lymphoblastic leukemia $[189,191,192]$. Of note, this compound is the first DUB inhibitor to enter in clinical trial for the treatment of relapsed multiple myeloma (NCT02372240), although it has been suspended in Phase 1 for dose-limiting toxicity $[190,193,194]$.

Despite UCHL5 and USP14 have very similar functions, selective inhibitors that individually target these enzymes have been identified. Among them, IU1 (1-[1-(4-fluorophenyl)-2,5-dimethyl1H-pyrrol-3-yl]-2-pyrrolidin-1-yl-ethanone) and its analogues are reversible small molecules that block specifically USP14 catalytic site and their antitumor effects have been recently tested in in vitro and in vivo studies for breast and lung cancers [195-198].

In the last decade, DUBs inhibitors are also emerged as versatile tools to define the structure and the cellular functions of these proteases. In addition, their potential application as anti-cancer agents stimulates the discovery of new and more specific antagonists. Research in this field could be particularly important, especially for those malignancies that have a complex biology such as HH-driven tumors. 
Table 1. Inhibitors of HH-related DUBs.

\begin{tabular}{|c|c|c|c|c|}
\hline DUB & Compound & $\begin{array}{l}\text { Cancer Type } \\
\text { (In Vitro and/or In Vivo Studies) }\end{array}$ & In Vivo Drug Administration & References \\
\hline \multirow{12}{*}{ USP7 } & HBX 41,108 & Colon cancer & - & [146] \\
\hline & HBX 19,818 & Colon cancer & - & [147] \\
\hline & P22077 & $\begin{array}{l}\text { Neuroblastoma, } \\
\text { Non-small cell lung cancer, } \\
\text { Medulloblastoma, } \\
\text { Hepatocellular carcinoma }\end{array}$ & $\begin{array}{l}\text { Neuroblastoma orthotopic xenograft and hepatocellular carcinoma allograft } \\
\text { mouse models: IP injection with P22077 dissolved in DMSO. }\end{array}$ & {$[113,148,151-154]$} \\
\hline & P5091 & $\begin{array}{l}\text { Multiple Myeloma, Colorectal cancer, } \\
\text { Prostate cancer, } \\
\text { Ovarian cancer, Urothelial bladder cancer, } \\
\text { Esophageal squamous cell carcinoma, } \\
\text { Chronic lymphocytic leukemia, } \\
\text { Medulloblastoma }\end{array}$ & $\begin{array}{l}\text { Multiple myeloma xenograft mouse model: IV injection of } \mathrm{P} 5091 \text { dissolved in } \\
4 \% \text { NMP (N-methyl-2 Pyrrolidone), } 4 \% \text { Tween- } 80 \text {, and } 92 \% \mathrm{H}_{2} \mathrm{O} \text {. } \\
\text { Colorectal cancer xenograft mouse model: IP injection of P5091 dissolved in } \\
4 \% \text { NMP, 3\%, Tween- } 80 \text { and } 20 \% \text {, PEG400 in } \mathrm{H}_{2} \mathrm{O} \text {. } \\
\text { Esophageal squamous cell carcinoma xenograft mouse model: SC injection of } \\
\text { P5091 dissolved in DMSO and 10\% 2-hydroxypropyl- } \beta \text {-cyclodextrin (HPBCD). }\end{array}$ & {$[113,150,156-162]$} \\
\hline & XL188 & Ewing's Sarcoma & - & {$[163,164]$} \\
\hline & FT671 & $\begin{array}{l}\text { Colon cancer, } \\
\text { Osteosarcoma Neuroblastoma, } \\
\text { Multiple Myeloma }\end{array}$ & $\begin{array}{l}\text { Multiple myeloma xenograft mouse model: oral gavage of FT671 dissolved in } \\
10 \% \text { DMA, } 90 \% \text { PEG400. }\end{array}$ & [165] \\
\hline & Compound 4 & $\begin{array}{l}\text { Colon cancer, } \\
\text { Breast cancer, } \\
\text { Osteosarcoma, } \\
\text { Prostate cancer }\end{array}$ & - & [168] \\
\hline & GNE6640, GNE6776 & $\begin{array}{l}\text { Colon cancer, } \\
\text { Osteosarcoma, } \\
\text { Acute myeloid leukemia, } \\
\text { Breast cancer }\end{array}$ & $\begin{array}{l}\text { Acute Myeloid Leukemia and breast cancer xenograft mouse models: oral } \\
\text { gavage of GNE- } 6776 \text { dissolved in } 0.5 \% \text { methylcellulose, } 0.2 \% \text { Tween- } 80\end{array}$ & [166] \\
\hline & C7, C19 & $\begin{array}{l}\text { Colon cancer, } \\
\text { Multiple Myeloma, } \\
\text { Lung cancer }\end{array}$ & - & [167] \\
\hline & Spongiacidin $\mathrm{C}$ & Not reported & - & [169] \\
\hline & XL177A & $\begin{array}{l}\text { Breast cancer, } \\
\text { Ewing's Sarcoma }\end{array}$ & - & {$[170]$} \\
\hline & Compound 41 & $\begin{array}{l}\text { Multiple Myeloma, } \\
\text { Small cell lung cancer }\end{array}$ & $\begin{array}{l}\text { Multiple Myeloma and small cell lung cancer xenograft mouse models: oral } \\
\text { gavage. }\end{array}$ & {$[171]$} \\
\hline
\end{tabular}


Table 1. Cont

\begin{tabular}{|c|c|c|c|c|}
\hline \multirow[t]{2}{*}{ USP8 } & $\begin{array}{l}\text { 9-ethyloxyimino- } \\
\text { 9H-indeno }[1,2-b] \\
\text { pyrazine-2,3- } \\
\text { dicarbonitrile }\end{array}$ & Non-small cell lung cancer & Non-small cell lung cancer xenograft mouse model: IP injection. & {$[172,173]$} \\
\hline & Ubv.8.2 & Glioblastoma & - & {$[174,175]$} \\
\hline \multirow[t]{2}{*}{$\begin{array}{l}\text { UCHL5 } \\
\text { USP14 }\end{array}$} & b-AP15 & $\begin{array}{l}\text { Squamous cell carcinoma, } \\
\text { lung carcinoma, } \\
\text { Colon cancer, } \\
\text { Breast cancer, } \\
\text { Acute myeloid leukemia, } \\
\text { Multiple myeloma, } \\
\text { Prostate cancer, } \\
\text { Melanoma, } \\
\text { Large B cell lymphoma, } \\
\text { Neuroblastoma, } \\
\text { Ewing's sarcoma, } \\
\text { Hepatocellular carcinoma }\end{array}$ & $\begin{array}{l}\text { Squamous cell carcinoma, Lewis lung carcinoma, colon cancer, breast cancer } \\
\text { xenograft and acute myeloid leukemia allograft mouse models: b-AP15 } \\
\text { dissolved in Cremophor EL and polyethylene glycol } 400 \text { (1:1). } \\
\text { Multiple myeloma xenograft mouse model: IV injection of b-AP15 dissolved in } \\
\text { Cremophor EL/polyethylene glycol } 400 \text { (1:1). } \\
\text { Prostate cancer xenograft mouse model: b-AP15 dissolved in a vehicle } \\
\text { composed by DMSO, Cremophor and } 0.85 \% \mathrm{NaCl} \text { at (1:3:6) ratio. } \\
\text { Melanoma xenograft mouse model: IP injection of b-AP15 dissolved in 90:1:9 } \\
\text { mix of Labrafil:Tween 80:DMA. } \\
\text { Large B cell lymphoma xenograft mouse model: IP injection of b-AP15 } \\
\text { dissolved in Cremophor.EL: PEG400: saline (2:2:4). } \\
\text { Neuroblastoma and Ewing's sarcoma xenograft mouse models: b-AP15 } \\
\text { dissolved in DMSO. }\end{array}$ & [178-189] \\
\hline & VLX1570 & $\begin{array}{l}\text { Ewing's sarcoma, } \\
\text { Multiple myeloma, } \\
\text { Endometrial cancer, } \\
\text { Acute lymphoblastic leukemia }\end{array}$ & $\begin{array}{l}\text { Ewing's sarcoma xenograft mouse model: IP injection of VLX1570 dissolved in } \\
\text { DMSO. } \\
\text { Multiple myeloma orthotopic xenograft mouse model: IV injection of VLX1570 } \\
\text { dissolved in PEG:Chemophore:Tween ( } 50: 10: 40 \text { ). } \\
\text { Relapsed Multiple myeloma patients (clinical trial NCT02372240): IV infusion. }\end{array}$ & [189-193] \\
\hline USP14 & IU1 and analogues & $\begin{array}{l}\text { Breast cancer, } \\
\text { Lung cancer }\end{array}$ & - & [195-198] \\
\hline
\end{tabular}

IP: intraperitoneal; IV: intravenous; SC: subcutaneous. 
Table 2. Chemical structures of DUBs inhibitors reported in Table 1.

\begin{tabular}{|c|c|c|c|}
\hline Target & Compound & Structure & References \\
\hline & HBX 41,108 & & [146] \\
\hline & HBX 19,818 & & [147] \\
\hline & P22077 & & {$[148,149]$} \\
\hline & P5091 & & [150] \\
\hline & XL188 & & [163] \\
\hline & FT671 & & [165] \\
\hline & Compound 4 & & [168] \\
\hline & GNE6640 & & [166] \\
\hline & GNE6776 & & [166] \\
\hline & $\mathrm{C} 7$ & & [167] \\
\hline & C19 & & [167] \\
\hline & Spongiacidin C & & [169] \\
\hline & XL177A & & [170] \\
\hline & Compound 41 & & [171] \\
\hline
\end{tabular}


Table 2. Cont.

\begin{tabular}{cccc}
\hline Target & Compound & $\begin{array}{c}\text { 9-ethyloxyimino- } \\
\text { 9H-indeno[1,2-b] } \\
\text { pyrazine-2,3- } \\
\text { dicarbonitrile }\end{array}$ RSP8 \\
UCHL5 & b-AP15 & [172] & [178] \\
USP14 & ILX1570 & [189]
\end{tabular}

\section{Conclusions}

The HH pathway is involved in the tumorigenesis of several malignancies and has emerged as a valid therapeutic target for anti-cancer therapy. At present, the main strategies to impair $\mathrm{HH}$ signaling are focused on inhibitors acting either on SMO or on GLIs, or through multi-targeting approaches working on both upstream and downstream levels $[52,199,200]$. A number of SMO antagonists have entered in clinical phases but only two of them, vismodegib and sonidegib, have been approved by the FDA for the treatment of BCC. Nevertheless, the response to SMO antagonists has been variable in other $\mathrm{HH}$-dependent tumors such as $\mathrm{MB}$, showing relapse due to lack of efficacy on SMO drug-resistant mutations and SMO-independent $\mathrm{HH}$ activation [201-203]. These limitations arose the need to develop alternative approaches. Even if GLI inhibitors have shown promising results in preclinical studies, few of them have entered in clinical studies, and only the Arsenic Trioxide (ATO) has been approved by FDA for the treatment of AML $[33,34,51,200]$. Currently, ATO is in several clinical trials for both solid tumors and hematological malignancies, but there are only preclinical studies for some HH-driven cancers such as MB. These results highlight that further efforts need to be spent on the development of more effective anti-cancer strategies for the treatment of HH-dependent tumors. In the last years, the possibility of hitting a tumorigenic pathway at multiple regulatory levels has emerging as a valid therapeutic frontier in the field of oncological research. The genetic and molecular heterogeneity of $\mathrm{HH}$-driven malignancies stimulates the identification of novel molecular players of this pathway as potential druggable targets. In particular, ubiquitylation deeply rules $\mathrm{HH}$ signaling, and its pharmacological inhibition is an attractive tool to hinder this pathway at a further crucial level of regulation. In this regard, DUBs are emerging as interesting therapeutic targets in various $\mathrm{HH}$-related tumors given their positive role in the control of the main performers of $\mathrm{HH}$ signaling. In addition to promoting the activity of SMO and GLIs, as here reviewed, DUBs affects $\mathrm{HH}$ signaling regulating ciliogenesis and the ciliary recruitment of $\mathrm{HH}$ regulatory proteins, as described for USP14 [177]. Moreover, multiple components of the HH pathway can be stabilized by the activity of DUBs. USP8, here presented for the function exerted on Smo, also regulates Itch, a HECT E3 ligase involved in GLI1 ubiquitylation. [204,205]. Notably, USP17, FAM/USP9X, and YOD1 have also been identified as modulators of Itch activity, enhancing its stability [206-208]. Recently, the involvement of $\beta \operatorname{TrCP}$-bound deubiquitylase enzyme USP47 has been described in $\mathrm{HH}$ signaling. The interaction of the positive $\mathrm{HH}$ regulator ERAP1 with USP47 induces the degradation of $\beta \operatorname{TrCP}$, thus protecting GLIs from $\beta$ TrCP-dependent degradation and stimulating $\mathrm{HH}$ activity [209]. 
Increasing findings in this field of study highlight the interest in the development of more efficient and selective DUBs inhibitors for anti-cancer therapy, without affecting the fine physiologic balance of the $\mathrm{Ub}$ proteasome system that governs the proper functioning of all pathways, including $\mathrm{HH}$.

Author Contributions: P.I. and L.D.M. developed the concept and wrote the manuscript. All the authors contributed to the writing and to prepare the figures. All authors have read and agreed to the published version of the manuscript.

Funding: This work was supported by Associazione Italiana Ricerca Cancro (AIRC) Grant \#IG20801, Ministry of University and Research (PRIN 2017BF3PXZ003), Progetti di Ricerca di Università Sapienza di Roma, Universities and Research-Dipartimenti di Eccellenza-L.232/2016, Pasteur Institute/Cenci Bolognetti Foundation, and Istituto Italiano di Tecnologia (IIT).

Conflicts of Interest: The authors declare no conflicts of interest.

\section{References}

1. Ingham, P.W.; McMahon, A.P. Hedgehog signaling in animal development: Paradigms and principles. Genes Dev. 2001, 15, 3059-3087. [CrossRef] [PubMed]

2. Briscoe, J.; Thérond, P.P. The mechanisms of Hedgehog signalling and its roles in development and disease. Nat. Rev. Mol. Cell Biol. 2013, 14, 416-429. [CrossRef] [PubMed]

3. Varjosalo, M.; Taipale, J. Hedgehog: Functions and mechanisms. Genes Dev. 2008, 22, 2454-2472. [CrossRef] [PubMed]

4. Petrova, R.; Joyner, A.L. Roles for Hedgehog signaling in adult organ homeostasis and repair. Development 2014, 141, 3445-3457. [CrossRef] [PubMed]

5. Lee, R.T.; Zhao, Z.; Ingham, P.W. Hedgehog signalling. Development 2016, 143, 367-372. [CrossRef] [PubMed]

6. Huangfu, D.; Anderson, K.V. Signaling from Smo to Ci/Gli: Conservation and divergence of Hedgehog pathways from Drosophila to vertebrates. Development 2006, 133, 3-14. [CrossRef] [PubMed]

7. Pathi, S.; Pagan-Westphal, S.; Baker, D.P.; Garber, E.A.; Rayhorn, P.; Bumcrot, D.; Tabin, C.J.; Blake Pepinsky, R.; Williams, K.P. Comparative biological responses to human Sonic, Indian, and Desert hedgehog. Mech. Dev. 2001, 106, 107-117. [CrossRef]

8. Kong, J.H.; Siebold, C.; Rohatgi, R. Biochemical mechanisms of vertebrate hedgehog signaling. Development 2019, 146. [CrossRef] [PubMed]

9. Hui, C.C.; Angers, S. Gli proteins in development and disease. Annu. Rev. Cell Dev. Biol. 2011, 27, 513-537. [CrossRef] [PubMed]

10. Infante, P.; Faedda, R.; Bernardi, F.; Bufalieri, F.; Lospinoso Severini, L.; Alfonsi, R.; Mazzà, D.; Siler, M.; Coni, S.; Po, A.; et al. Itch/ $\beta$-arrestin2-dependent non-proteolytic ubiquitylation of SuFu controls Hedgehog signalling and medulloblastoma tumorigenesis. Nat. Commun. 2018, 9, 976. [CrossRef] [PubMed]

11. Tukachinsky, H.; Lopez, L.V.; Salic, A. A mechanism for vertebrate Hedgehog signaling: Recruitment to cilia and dissociation of SuFu-Gli protein complexes. J. Cell Biol. 2010, 191, 415-428. [CrossRef]

12. Yao, E.; Chuang, P.T. Hedgehog signaling: From basic research to clinical applications. J. Formos. Med. Assoc. 2015, 114, 569-576. [CrossRef] [PubMed]

13. Montagnani, V.; Stecca, B. Role of Protein Kinases in Hedgehog Pathway Control and Implications for Cancer Therapy. Cancers 2019, 11, 449. [CrossRef] [PubMed]

14. Liu, A. Proteostasis in the Hedgehog signaling pathway. Semin. Cell Dev. Biol. 2019, 93, 153-163. [CrossRef]

15. Hsia, E.Y.; Gui, Y.; Zheng, X. Regulation of Hedgehog signaling by ubiquitination. Front. Biol. (Beijing) 2015, 10, 203-220. [CrossRef] [PubMed]

16. Niewiadomski, P.; Kong, J.H.; Ahrends, R.; Ma, Y.; Humke, E.W.; Khan, S.; Teruel, M.N.; Novitch, B.G.; Rohatgi, R. Gli protein activity is controlled by multisite phosphorylation in vertebrate Hedgehog signaling. Cell Rep. 2014, 6, 168-181. [CrossRef] [PubMed]

17. Huntzicker, E.G.; Estay, I.S.; Zhen, H.; Lokteva, L.A.; Jackson, P.K.; Oro, A.E. Dual degradation signals control Gli protein stability and tumor formation. Genes Dev. 2006, 20, 276-281. [CrossRef] [PubMed]

18. Di Marcotullio, L.; Ferretti, E.; Greco, A.; De Smaele, E.; Screpanti, I.; Gulino, A. Multiple ubiquitin-dependent processing pathways regulate hedgehog/gli signaling: Implications for cell development and tumorigenesis. Cell Cycle 2007, 6, 390-393. [CrossRef] [PubMed]

19. Jiang, J. Regulation of Hh/Gli signaling by dual ubiquitin pathways. Cell Cycle 2006, 5, 2457-2463. [CrossRef] 
20. Wang, C.; Pan, Y.; Wang, B. Suppressor of fused and Spop regulate the stability, processing and function of Gli2 and Gli3 full-length activators but not their repressors. Development 2010, 137, 2001-2009. [CrossRef]

21. Gulino, A.; Di Marcotullio, L.; Canettieri, G.; De Smaele, E.; Screpanti, I. Hedgehog/Gli control by ubiquitination/acetylation interplay. Vitam. Horm. 2012, 88, 211-227. [CrossRef] [PubMed]

22. Infante, P.; Lospinoso Severini, L.; Bernardi, F.; Bufalieri, F.; Di Marcotullio, L. Targeting Hedgehog Signalling through the Ubiquitylation Process: The Multiple Roles of the HECT-E3 Ligase Itch. Cells 2019, 8, 98. [CrossRef] [PubMed]

23. Di Marcotullio, L.; Ferretti, E.; Greco, A.; De Smaele, E.; Po, A.; Sico, M.A.; Alimandi, M.; Giannini, G.; Maroder, M.; Screpanti, I.; et al. Numb is a suppressor of Hedgehog signalling and targets Gli1 for Itch-dependent ubiquitination. Nat. Cell Biol. 2006, 8, 1415-1423. [CrossRef] [PubMed]

24. Di Marcotullio, L.; Greco, A.; Mazzà, D.; Canettieri, G.; Pietrosanti, L.; Infante, P.; Coni, S.; Moretti, M.; De Smaele, E.; Ferretti, E.; et al. Numb activates the E3 ligase Itch to control Gli1 function through a novel degradation signal. Oncogene 2011, 30, 65-76. [CrossRef] [PubMed]

25. Mazzà, D.; Infante, P.; Colicchia, V.; Greco, A.; Alfonsi, R.; Siler, M.; Antonucci, L.; Po, A.; De Smaele, E.; Ferretti, E.; et al. PCAF ubiquitin ligase activity inhibits Hedgehog/Gli1 signaling in p53-dependent response to genotoxic stress. Cell Death Differ. 2013, 20, 1688-1697. [CrossRef] [PubMed]

26. Li, S.; Chen, Y.; Shi, Q.; Yue, T.; Wang, B.; Jiang, J. Hedgehog-regulated ubiquitination controls smoothened trafficking and cell surface expression in Drosophila. PLoS Biol. 2012, 10, e1001239. [CrossRef] [PubMed]

27. Li, S.; Wang, B.; Jiang, J. Hedgehog reciprocally controls trafficking of Smo and Ptc through the Smurf family of E3 ubiquitin ligases. Sci. Signal. 2018, 11. [CrossRef]

28. Li, S.; Cho, Y.S.; Wang, B.; Jiang, J. Regulation of Smoothened ubiquitylation and cell surface expression through a Cul4-DDB1-G $\beta$ E3 ubiquitin ligase complex. J. Cell Sci. 2018, 131. [CrossRef]

29. Sun, X.; Sun, B.; Cui, M.; Zhou, Z. HERC4 exerts an anti-tumor role through destabilizing the oncoprotein Smo. Biochem. Biophys. Res. Commun. 2019, 513, 1013-1018. [CrossRef] [PubMed]

30. McMahon, A.P.; Ingham, P.W.; Tabin, C.J. Developmental roles and clinical significance of hedgehog signaling. Curr. Top. Dev. Biol. 2003, 53, 1-114. [CrossRef] [PubMed]

31. Ruiz i Altaba, A.; Sánchez, P.; Dahmane, N. Gli and hedgehog in cancer: Tumours, embryos and stem cells. Nat. Rev. Cancer 2002, 2, 361-372. [CrossRef] [PubMed]

32. Skoda, A.M.; Simovic, D.; Karin, V.; Kardum, V.; Vranic, S.; Serman, L. The role of the Hedgehog signaling pathway in cancer: A comprehensive review. Bosn. J. Basic Med. Sci. 2018, 18, 8-20. [CrossRef] [PubMed]

33. Didiasova, M.; Schaefer, L.; Wygrecka, M. Targeting GLI Transcription Factors in Cancer. Molecules 2018, 23, 1003. [CrossRef] [PubMed]

34. Peer, E.; Tesanovic, S.; Aberger, F. Next-Generation Hedgehog/GLI Pathway Inhibitors for Cancer Therapy. Cancers 2019, 11, 538. [CrossRef] [PubMed]

35. Huang, S.Y.; Yang, J.Y. Targeting the Hedgehog Pathway in Pediatric Medulloblastoma. Cancers 2015, 7, 2110-2123. [CrossRef] [PubMed]

36. Hutchin, M.E.; Kariapper, M.S.; Grachtchouk, M.; Wang, A.; Wei, L.; Cummings, D.; Liu, J.; Michael, L.E.; Glick, A.; Dlugosz, A.A. Sustained Hedgehog signaling is required for basal cell carcinoma proliferation and survival: Conditional skin tumorigenesis recapitulates the hair growth cycle. Genes Dev. 2005, 19, $214-223$. [CrossRef] [PubMed]

37. Scales, S.J.; De Sauvage, F.J. Mechanisms of Hedgehog pathway activation in cancer and implications for therapy. Trends Pharmacol. Sci. 2009, 30, 303-312. [CrossRef]

38. Lee, Y.; Kawagoe, R.; Sasai, K.; Li, Y.; Russell, H.R.; Curran, T.; McKinnon, P.J. Loss of suppressor-of-fused function promotes tumorigenesis. Oncogene 2007, 26, 6442-6447. [CrossRef] [PubMed]

39. De Smaele, E.; Di Marcotullio, L.; Ferretti, E.; Screpanti, I.; Alesse, E.; Gulino, A. Chromosome 17p deletion in human medulloblastoma: A missing checkpoint in the Hedgehog pathway. Cell Cycle 2004, 3, 1263-1266. [CrossRef] [PubMed]

40. Rubin, L.L.; De Sauvage, F.J. Targeting the Hedgehog pathway in cancer. Nat. Rev. Drug Discov. 2006, 5, 1026-1033. [CrossRef]

41. Mukherjee, S.; Frolova, N.; Sadlonova, A.; Novak, Z.; Steg, A.; Page, G.P.; Welch, D.R.; Lobo-Ruppert, S.M.; Ruppert, J.M.; Johnson, M.R.; et al. Hedgehog signaling and response to cyclopamine differ in epithelial and stromal cells in benign breast and breast cancer. Cancer Biol. Ther. 2006, 5, 674-683. [CrossRef] [PubMed] 
42. Thayer, S.P.; Di Magliano, M.P.; Heiser, P.W.; Nielsen, C.M.; Roberts, D.J.; Lauwers, G.Y.; Qi, Y.P.; Gysin, S.; Fernández-del Castillo, C.; Yajnik, V.; et al. Hedgehog is an early and late mediator of pancreatic cancer tumorigenesis. Nature 2003, 425, 851-856. [CrossRef] [PubMed]

43. Varnat, F.; Duquet, A.; Malerba, M.; Zbinden, M.; Mas, C.; Gervaz, P.; Ruiz i Altaba, A. Human colon cancer epithelial cells harbour active HEDGEHOG-GLI signalling that is essential for tumour growth, recurrence, metastasis and stem cell survival and expansion. EMBO Mol. Med. 2009, 1, 338-351. [CrossRef] [PubMed]

44. Amakye, D.; Jagani, Z.; Dorsch, M. Unraveling the therapeutic potential of the Hedgehog pathway in cancer. Nat. Med. 2013, 19, 1410-1422. [CrossRef] [PubMed]

45. Fan, L.; Pepicelli, C.V.; Dibble, C.C.; Catbagan, W.; Zarycki, J.L.; Laciak, R.; Gipp, J.; Shaw, A.; Lamm, M.L.; Munoz, A.; et al. Hedgehog signaling promotes prostate xenograft tumor growth. Endocrinology 2004, 145, 3961-3970. [CrossRef] [PubMed]

46. Dierks, C.; Grbic, J.; Zirlik, K.; Beigi, R.; Englund, N.P.; Guo, G.R.; Veelken, H.; Engelhardt, M.; Mertelsmann, R.; Kelleher, J.F.; et al. Essential role of stromally induced hedgehog signaling in B-cell malignancies. Nat. Med. 2007, 13, 944-951. [CrossRef] [PubMed]

47. Becher, O.J.; Hambardzumyan, D.; Fomchenko, E.I.; Momota, H.; Mainwaring, L.; Bleau, A.M.; Katz, A.M.; Edgar, M.; Kenney, A.M.; Cordon-Cardo, C.; et al. Gli activity correlates with tumor grade in platelet-derived growth factor-induced gliomas. Cancer Res. 2008, 68, 2241-2249. [CrossRef] [PubMed]

48. Clement, V.; Sanchez, P.; De Tribolet, N.; Radovanovic, I.; Ruiz i Altaba, A. HEDGEHOG-GLI1 signaling regulates human glioma growth, cancer stem cell self-renewal, and tumorigenicity. Curr. Biol. 2007, 17, 165-172. [CrossRef] [PubMed]

49. Miele, E.; Po, A.; Begalli, F.; Antonucci, L.; Mastronuzzi, A.; Marras, C.E.; Carai, A.; Cucchi, D.; Abballe, L.; Besharat, Z.M.; et al. $\beta$-arrestin1-mediated acetylation of Gli1 regulates Hedgehog/Gli signaling and modulates self-renewal of SHH medulloblastoma cancer stem cells. BMC Cancer 2017, 17, 488. [CrossRef] [PubMed]

50. Po, A.; Ferretti, E.; Miele, E.; De Smaele, E.; Paganelli, A.; Canettieri, G.; Coni, S.; Di Marcotullio, L.; Biffoni, M.; Massimi, L.; et al. Hedgehog controls neural stem cells through p53-independent regulation of Nanog. EMBO J. 2010, 29, 2646-2658. [CrossRef] [PubMed]

51. Infante, P.; Alfonsi, R.; Botta, B.; Mori, M.; Di Marcotullio, L. Targeting GLI factors to inhibit the Hedgehog pathway. Trends Pharmacol. Sci. 2015, 36, 547-558. [CrossRef] [PubMed]

52. Quaglio, D.; Infante, P.; Di Marcotullio, L.; Botta, B.; Mori, M. Hedgehog signaling pathway inhibitors: An updated patent review (2015-present). Expert Opin. Ther. Pat. 2020, 30, 235-250. [CrossRef] [PubMed]

53. Finley, D.; Bartel, B.; Varshavsky, A. The tails of ubiquitin precursors are ribosomal proteins whose fusion to ubiquitin facilitates ribosome biogenesis. Nature 1989, 338, 394-401. [CrossRef] [PubMed]

54. Hershko, A.; Ciechanover, A. The ubiquitin system. Annu. Rev. Biochem. 1998, 67, 425-479. [CrossRef] [PubMed]

55. Ye, Y.; Rape, M. Building ubiquitin chains: E2 enzymes at work. Nat. Rev. Mol. Cell Biol. 2009, 10, 755-764. [CrossRef] [PubMed]

56. Zhao, Y.; Sun, Y. Cullin-RING Ligases as attractive anti-cancer targets. Curr. Pharm. Des. 2013, 19, 3215-3225. [CrossRef] [PubMed]

57. Metzger, M.B.; Hristova, V.A.; Weissman, A.M. HECT and RING finger families of E3 ubiquitin ligases at a glance. J. Cell Sci. 2012, 125, 531-537. [CrossRef] [PubMed]

58. Walden, H.; Rittinger, K. RBR ligase-mediated ubiquitin transfer: A tale with many twists and turns. Nat. Struct. Mol. Biol. 2018, 25, 440-445. [CrossRef] [PubMed]

59. Ciechanover, A.; Ben-Saadon, R. N-terminal ubiquitination: More protein substrates join in. Trends Cell Biol. 2004, 14, 103-106. [CrossRef] [PubMed]

60. Pavri, R.; Zhu, B.; Li, G.; Trojer, P.; Mandal, S.; Shilatifard, A.; Reinberg, D. Histone H2B monoubiquitination functions cooperatively with FACT to regulate elongation by RNA polymerase II. Cell 2006, 125, 703-717. [CrossRef] [PubMed]

61. Su, Y.T.; Gao, C.; Liu, Y.; Guo, S.; Wang, A.; Wang, B.; Erdjument-Bromage, H.; Miyagi, M.; Tempst, P.; Kao, H.Y. Monoubiquitination of filamin B regulates vascular endothelial growth factor-mediated trafficking of histone deacetylase 7. Mol. Cell Biol. 2013, 33, 1546-1560. [CrossRef] [PubMed] 
62. Braten, O.; Livneh, I.; Ziv, T.; Admon, A.; Kehat, I.; Caspi, L.H.; Gonen, H.; Bercovich, B.; Godzik, A.; Jahandideh, S.; et al. Numerous proteins with unique characteristics are degraded by the $26 \mathrm{~S}$ proteasome following monoubiquitination. Proc. Natl. Acad. Sci. USA 2016, 113, E4639-E4647. [CrossRef] [PubMed]

63. Pickart, C.M. Mechanisms underlying ubiquitination. Annu. Rev. Biochem. 2001, 70, 503-533. [CrossRef] [PubMed]

64. Thrower, J.S.; Hoffman, L.; Rechsteiner, M.; Pickart, C.M. Recognition of the polyubiquitin proteolytic signal. EMBO J. 2000, 19, 94-102. [CrossRef] [PubMed]

65. Komander, D.; Rape, M. The ubiquitin code. Annu. Rev. Biochem. 2012, 81, 203-229. [CrossRef] [PubMed]

66. Swatek, K.N.; Komander, D. Ubiquitin modifications. Cell Res. 2016, 26, 399-422. [CrossRef] [PubMed]

67. Husnjak, K.; Dikic, I. Ubiquitin-binding proteins: Decoders of ubiquitin-mediated cellular functions. Annu. Rev. Biochem. 2012, 81, 291-322. [CrossRef] [PubMed]

68. Mevissen, T.E.; Hospenthal, M.K.; Geurink, P.P.; Elliott, P.R.; Akutsu, M.; Arnaudo, N.; Ekkebus, R.; Kulathu, Y.; Wauer, T.; El Oualid, F.; et al. OTU deubiquitinases reveal mechanisms of linkage specificity and enable ubiquitin chain restriction analysis. Cell 2013, 154, 169-184. [CrossRef] [PubMed]

69. Nijman, S.M.; Luna-Vargas, M.P.; Velds, A.; Brummelkamp, T.R.; Dirac, A.M.; Sixma, T.K.; Bernards, R. A genomic and functional inventory of deubiquitinating enzymes. Cell 2005, 123, 773-786. [CrossRef] [PubMed]

70. Clague, M.J.; Urbé, S.; Komander, D. Breaking the chains: Deubiquitylating enzyme specificity begets function. Nat. Rev. Mol. Cell Biol. 2019, 20, 338-352. [CrossRef] [PubMed]

71. Faesen, A.C.; Luna-Vargas, M.P.; Geurink, P.P.; Clerici, M.; Merkx, R.; Van Dijk, W.J.; Hameed, D.S.; El Oualid, F.; Ovaa, H.; Sixma, T.K. The differential modulation of USP activity by internal regulatory domains, interactors and eight ubiquitin chain types. Chem. Biol. 2011, 18, 1550-1561. [CrossRef] [PubMed]

72. Mevissen, T.E.T.; Komander, D. Mechanisms of Deubiquitinase Specificity and Regulation. Annu. Rev. Biochem. 2017, 86, 159-192. [CrossRef] [PubMed]

73. Urbé, S.; Liu, H.; Hayes, S.D.; Heride, C.; Rigden, D.J.; Clague, M.J. Systematic survey of deubiquitinase localization identifies USP21 as a regulator of centrosome- and microtubule-associated functions. Mol. Biol. Cell 2012, 23, 1095-1103. [CrossRef] [PubMed]

74. Alcedo, J.; Ayzenzon, M.; Von Ohlen, T.; Noll, M.; Hooper, J.E. The Drosophila smoothened gene encodes a seven-pass membrane protein, a putative receptor for the hedgehog signal. Cell 1996, 86, 221-232. [CrossRef]

75. Van den Heuvel, M.; Ingham, P.W. Smoothened encodes a receptor-like serpentine protein required for hedgehog signalling. Nature 1996, 382, 547-551. [CrossRef] [PubMed]

76. Denef, N.; Neubüser, D.; Perez, L.; Cohen, S.M. Hedgehog induces opposite changes in turnover and subcellular localization of patched and smoothened. Cell 2000, 102, 521-531. [CrossRef]

77. Zhu, A.J.; Zheng, L.; Suyama, K.; Scott, M.P. Altered localization of Drosophila Smoothened protein activates Hedgehog signal transduction. Genes Dev. 2003, 17, 1240-1252. [CrossRef] [PubMed]

78. Corbit, K.C.; Aanstad, P.; Singla, V.; Norman, A.R.; Stainier, D.Y.; Reiter, J.F. Vertebrate Smoothened functions at the primary cilium. Nature 2005, 437, 1018-1021. [CrossRef] [PubMed]

79. Rohatgi, R.; Milenkovic, L.; Corcoran, R.B.; Scott, M.P. Hedgehog signal transduction by Smoothened: Pharmacologic evidence for a 2-step activation process. Proc. Natl. Acad. Sci. USA 2009, 106, 3196-3201. [CrossRef] [PubMed]

80. Jia, J.; Tong, C.; Wang, B.; Luo, L.; Jiang, J. Hedgehog signalling activity of Smoothened requires phosphorylation by protein kinase A and casein kinase I. Nature 2004, 432, 1045-1050. [CrossRef] [PubMed]

81. Zhang, C.; Williams, E.H.; Guo, Y.; Lum, L.; Beachy, P.A. Extensive phosphorylation of Smoothened in Hedgehog pathway activation. Proc. Natl. Acad. Sci. USA 2004, 101, 17900-17907. [CrossRef] [PubMed]

82. Apionishev, S.; Katanayeva, N.M.; Marks, S.A.; Kalderon, D.; Tomlinson, A. Drosophila Smoothened phosphorylation sites essential for Hedgehog signal transduction. Nat. Cell Biol. 2005, 7, 86-92. [CrossRef]

83. Chen, Y.; Sasai, N.; Ma, G.; Yue, T.; Jia, J.; Briscoe, J.; Jiang, J. Sonic Hedgehog dependent phosphorylation by CK1 $\alpha$ and GRK2 is required for ciliary accumulation and activation of smoothened. PLoS Biol. 2011, 9, e1001083. [CrossRef] [PubMed]

84. Xia, R.; Jia, H.; Fan, J.; Liu, Y.; Jia, J. USP8 promotes smoothened signaling by preventing its ubiquitination and changing its subcellular localization. PLoS Biol. 2012, 10, e1001238. [CrossRef] [PubMed] 
85. Dufner, A.; Knobeloch, K.P. Ubiquitin-specific protease 8 (USP8/UBPy): A prototypic multidomain deubiquitinating enzyme with pleiotropic functions. Biochem. Soc. Trans. 2019, 47, 1867-1879. [CrossRef] [PubMed]

86. Ma, G.; Li, S.; Han, Y.; Yue, T.; Wang, B.; Jiang, J. Regulation of Smoothened Trafficking and Hedgehog Signaling by the SUMO Pathway. Dev. Cell 2016, 39, 438-451. [CrossRef] [PubMed]

87. Zhou, Z.; Yao, X.; Pang, S.; Chen, P.; Jiang, W.; Shan, Z.; Zhang, Q. The deubiquitinase UCHL5/UCH37 positively regulates Hedgehog signaling by deubiquitinating Smoothened. J. Mol. Cell Biol. 2018, 10, $243-257$. [CrossRef]

88. Wicks, S.J.; Haros, K.; Maillard, M.; Song, L.; Cohen, R.E.; Dijke, P.T.; Chantry, A. The deubiquitinating enzyme UCH37 interacts with Smads and regulates TGF-beta signalling. Oncogene 2005, 24, 8080-8084. [CrossRef] [PubMed]

89. Mahanic, C.S.; Budhavarapu, V.; Graves, J.D.; Li, G.; Lin, W.C. Regulation of E2 promoter binding factor 1 (E2F1) transcriptional activity through a deubiquitinating enzyme, UCH37. J. Biol. Chem. 2015, 290, 26508-26522. [CrossRef]

90. Jiao, L.; Ouyang, S.; Shaw, N.; Song, G.; Feng, Y.; Niu, F.; Qiu, W.; Zhu, H.; Hung, L.W.; Zuo, X.; et al. Mechanism of the Rpn13-induced activation of Uch37. Protein Cell 2014, 5, 616-630. [CrossRef] [PubMed]

91. Fan, J.; Jiang, K.; Liu, Y.; Jia, J. Hrs promotes ubiquitination and mediates endosomal trafficking of smoothened in Drosophila hedgehog signaling. PLoS ONE 2013, 8, e79021. [CrossRef] [PubMed]

92. Wang, L.; Chen, Y.J.; Xu, K.; Wang, Y.Y.; Shen, X.Z.; Tu, R.Q. High expression of UCH37 is significantly associated with poor prognosis in human epithelial ovarian cancer. Tumour Biol. 2014, 35, 11427-11433. [CrossRef] [PubMed]

93. Chen, Y.; Fu, D.; Xi, J.; Ji, Z.; Liu, T.; Ma, Y.; Zhao, Y.; Dong, L.; Wang, Q.; Shen, X. Expression and clinical significance of UCH37 in human esophageal squamous cell carcinoma. Dig. Dis. Sci. 2012, 57, 2310-2317. [CrossRef] [PubMed]

94. Fang, Y.; Mu, J.; Ma, Y.; Ma, D.; Fu, D.; Shen, X. The interaction between ubiquitin C-terminal hydrolase 37 and glucose-regulated protein 78 in hepatocellular carcinoma. Mol. Cell. Biochem. 2012, 359, 59-66. [CrossRef] [PubMed]

95. Jiang, W.; Yao, X.; Shan, Z.; Li, W.; Gao, Y.; Zhang, Q. E3 ligase Herc4 regulates Hedgehog signalling through promoting Smoothened degradation. J. Mol. Cell Biol. 2019, 11, 791-803. [CrossRef] [PubMed]

96. Angers, S.; Li, T.; Yi, X.; MacCoss, M.J.; Moon, R.T.; Zheng, N. Molecular architecture and assembly of the DDB1-CUL4A ubiquitin ligase machinery. Nature 2006, 443, 590-593. [CrossRef] [PubMed]

97. Pan, Y.; Bai, C.B.; Joyner, A.L.; Wang, B. Sonic hedgehog signaling regulates Gli2 transcriptional activity by suppressing its processing and degradation. Mol. Cell Biol. 2006, 26, 3365-3377. [CrossRef] [PubMed]

98. Wang, B.; Li, Y. Evidence for the direct involvement of $\{$ beta $\}$ TrCP in Gli3 protein processing. Proc. Natl. Acad. Sci. USA 2006, 103, 33-38. [CrossRef] [PubMed]

99. Di Marcotullio, L.; Ferretti, E.; De Smaele, E.; Screpanti, I.; Gulino, A. Suppressors of hedgehog signaling: Linking aberrant development of neural progenitors and tumorigenesis. Mol. Neurobiol. 2006, 34, 193-204. [CrossRef]

100. Infante, P.; Canettieri, G.; Gulino, A.; Di Marcotullio, L. Yin-Yang strands of PCAF/Hedgehog axis in cancer control. Trends Mol. Med. 2014, 20, 416-418. [CrossRef] [PubMed]

101. Everett, R.D.; Meredith, M.; Orr, A.; Cross, A.; Kathoria, M.; Parkinson, J. A novel ubiquitin-specific protease is dynamically associated with the PML nuclear domain and binds to a herpesvirus regulatory protein. EMBO J. 1997, 16, 1519-1530. [CrossRef] [PubMed]

102. Wang, Z.; Kang, W.; You, Y.; Pang, J.; Ren, H.; Suo, Z.; Liu, H.; Zheng, Y. USP7: Novel Drug Target in Cancer Therapy. Front. Pharmacol. 2019, 10, 427. [CrossRef] [PubMed]

103. Kon, N.; Kobayashi, Y.; Li, M.; Brooks, C.L.; Ludwig, T.; Gu, W. Inactivation of HAUSP in vivo modulates p53 function. Oncogene 2010, 29, 1270-1279. [CrossRef] [PubMed]

104. Kon, N.; Zhong, J.; Kobayashi, Y.; Li, M.; Szabolcs, M.; Ludwig, T.; Canoll, P.D.; Gu, W. Roles of HAUSP-mediated p53 regulation in central nervous system development. Cell Death Differ. 2011, 18, 1366-1375. [CrossRef] [PubMed] 
105. Fountain, M.D.; Oleson, D.S.; Rech, M.E.; Segebrecht, L.; Hunter, J.V.; McCarthy, J.M.; Lupo, P.J.; Holtgrewe, M.; Moran, R.; Rosenfeld, J.A.; et al. Pathogenic variants in USP7 cause a neurodevelopmental disorder with speech delays, altered behavior, and neurologic anomalies. Genet. Med. 2019, 21, 1797-1807. [CrossRef] [PubMed]

106. Zhou, Z.; Yao, X.; Li, S.; Xiong, Y.; Dong, X.; Zhao, Y.; Jiang, J.; Zhang, Q. Deubiquitination of Ci/Gli by Usp7/HAUSP Regulates Hedgehog Signaling. Dev. Cell 2015, 34, 58-72. [CrossRef] [PubMed]

107. Zhang, Q.; Zhang, L.; Wang, B.; Ou, C.Y.; Chien, C.T.; Jiang, J. A hedgehog-induced BTB protein modulates hedgehog signaling by degrading Ci/Gli transcription factor. Dev. Cell 2006, 10, 719-729. [CrossRef] [PubMed]

108. Zhang, Q.; Shi, Q.; Chen, Y.; Yue, T.; Li, S.; Wang, B.; Jiang, J. Multiple Ser/Thr-rich degrons mediate the degradation of Ci/Gli by the Cul3-HIB/SPOP E3 ubiquitin ligase. Proc. Natl. Acad. Sci. USA 2009, 106, 21191-21196. [CrossRef] [PubMed]

109. Zhu, L.; Liu, R.; Zhang, W.; Qian, S.; Wang, J.H. MicroRNA-205 regulates ubiquitin specific peptidase 7 protein expression in hepatocellular carcinoma cells. Mol. Med. Rep. 2015, 12, 4652-4656. [CrossRef] [PubMed]

110. Song, M.S.; Salmena, L.; Carracedo, A.; Egia, A.; Lo-Coco, F.; Teruya-Feldstein, J.; Pandolfi, P.P. The deubiquitinylation and localization of PTEN are regulated by a HAUSP-PML network. Nature 2008, 455, 813-817. [CrossRef] [PubMed]

111. Ostrom, Q.T.; Gittleman, H.; Truitt, G.; Boscia, A.; Kruchko, C.; Barnholtz-Sloan, J.S. CBTRUS Statistical Report: Primary Brain and Other Central Nervous System Tumors Diagnosed in the United States in 2011-2015. Neuro Oncol. 2018, 20, iv1-iv86. [CrossRef] [PubMed]

112. Ruiz i Altaba, A.; Palma, V.; Dahmane, N. Hedgehog-Gli signalling and the growth of the brain. Nat. Rev. Neurosci. 2002, 3, 24-33. [CrossRef] [PubMed]

113. Zhan, M.; Sun, X.; Liu, J.; Li, Y.; He, X.; Zhou, Z.; Lu, L. Usp7 promotes medulloblastoma cell survival and metastasis by activating Shh pathway. Biochem. Biophys. Res. Commun. 2017, 484, 429-434. [CrossRef] [PubMed]

114. De Jong, R.N.; Ab, E.; Diercks, T.; Truffault, V.; Daniëls, M.; Kaptein, R.; Folkers, G.E. Solution structure of the human ubiquitin-specific protease 15 DUSP domain. J. Biol. Chem. 2006, 281, 5026-5031. [CrossRef] [PubMed]

115. Li, S.; Wang, D.; Zhao, J.; Weathington, N.M.; Shang, D.; Zhao, Y. The deubiquitinating enzyme USP48 stabilizes TRAF2 and reduces E-cadherin-mediated adherens junctions. FASEB J. 2018, 32, 230-242. [CrossRef] [PubMed]

116. Uckelmann, M.; Densham, R.M.; Baas, R.; Winterwerp, H.H.K.; Fish, A.; Sixma, T.K.; Morris, J.R. USP48 restrains resection by site-specific cleavage of the BRCA1 ubiquitin mark from H2A. Nat. Commun. 2018, 9, 229. [CrossRef]

117. Courtois, G.; Fauvarque, M.O. The Many Roles of Ubiquitin in NF-кB Signaling. Biomedicines 2018, 6, 43. [CrossRef] [PubMed]

118. Cetkovská, K.; Šustová, H.; Uldrijan, S. Ubiquitin-specific peptidase 48 regulates Mdm2 protein levels independent of its deubiquitinase activity. Sci. Rep. 2017, 7, 43180. [CrossRef] [PubMed]

119. Quesada, V.; Díaz-Perales, A.; Gutiérrez-Fernández, A.; Garabaya, C.; Cal, S.; López-Otín, C. Cloning and enzymatic analysis of 22 novel human ubiquitin-specific proteases. Biochem. Biophys. Res. Commun. 2004, 314, 54-62. [CrossRef] [PubMed]

120. Luise, C.; Capra, M.; Donzelli, M.; Mazzarol, G.; Jodice, M.G.; Nuciforo, P.; Viale, G.; Di Fiore, P.P.; Confalonieri, S. An atlas of altered expression of deubiquitinating enzymes in human cancer. PLoS ONE 2011, 6, e15891. [CrossRef] [PubMed]

121. Zhou, A.; Lin, K.; Zhang, S.; Ma, L.; Xue, J.; Morris, S.A.; Aldape, K.D.; Huang, S. Gli1-induced deubiquitinase USP48 aids glioblastoma tumorigenesis by stabilizing Gli1. EMBO Rep. 2017, 18, 1318-1330. [CrossRef] [PubMed]

122. Jin, J.; Liu, J.; Chen, C.; Liu, Z.; Jiang, C.; Chu, H.; Pan, W.; Wang, X.; Zhang, L.; Li, B.; et al. The deubiquitinase USP21 maintains the stemness of mouse embryonic stem cells via stabilization of Nanog. Nat. Commun. 2016, 7, 13594. [CrossRef] [PubMed]

123. Li, W.; Cui, K.; Prochownik, E.V.; Li, Y. The deubiquitinase USP21 stabilizes MEK2 to promote tumor growth. Cell Death Dis. 2018, 9, 482. [CrossRef] [PubMed] 
124. Heride, C.; Rigden, D.J.; Bertsoulaki, E.; Cucchi, D.; De Smaele, E.; Clague, M.J.; Urbé, S. The centrosomal deubiquitylase USP21 regulates Gli1 transcriptional activity and stability. J. Cell Sci. 2016, 129, 4001-4013. [CrossRef] [PubMed]

125. Terrin, A.; Monterisi, S.; Stangherlin, A.; Zoccarato, A.; Koschinski, A.; Surdo, N.C.; Mongillo, M.; Sawa, A.; Jordanides, N.E.; Mountford, J.C.; et al. PKA and PDE4D3 anchoring to AKAP9 provides distinct regulation of cAMP signals at the centrosome. J. Cell Biol. 2012, 198, 607-621. [CrossRef] [PubMed]

126. Zhang, Q.X.; Wang, X.C.; Chen, S.P.; Qin, X.T. Predictive value of deubiquitination enzymes USP37 in the prognosis of breast cancer. Zhonghua Yi Xue Za Zhi 2016, 96, 944-948. [CrossRef] [PubMed]

127. Huang, X.; Summers, M.K.; Pham, V.; Lill, J.R.; Liu, J.; Lee, G.; Kirkpatrick, D.S.; Jackson, P.K.; Fang, G.; Dixit, V.M. Deubiquitinase USP37 is activated by CDK2 to antagonize APC(CDH1) and promote $S$ phase entry. Mol. Cell 2011, 42, 511-523. [CrossRef] [PubMed]

128. Burrows, A.C.; Prokop, J.; Summers, M.K. Skp1-Cul1-F-box ubiquitin ligase (SCF( $\beta \operatorname{TrCP}))$-mediated destruction of the ubiquitin-specific protease USP37 during G2-phase promotes mitotic entry. J. Biol. Chem. 2012, 287, 39021-39029. [CrossRef] [PubMed]

129. Cai, J.; Li, M.; Wang, X.; Li, L.; Li, Q.; Hou, Z.; Jia, H.; Liu, S. USP37 Promotes Lung Cancer Cell Migration by Stabilizing Snail Protein. Front. Genet. 2019, 10, 1324. [CrossRef] [PubMed]

130. Suresh, B.; Lee, J.; Kim, K.S.; Ramakrishna, S. The Importance of Ubiquitination and Deubiquitination in Cellular Reprogramming. Stem Cells Int. 2016, 2016, 6705927. [CrossRef] [PubMed]

131. Qin, T.; Li, B.; Feng, X.; Fan, S.; Liu, L.; Liu, D.; Mao, J.; Lu, Y.; Yang, J.; Yu, X.; et al. Abnormally elevated USP37 expression in breast cancer stem cells regulates stemness, epithelial-mesenchymal transition and cisplatin sensitivity. J. Exp. Clin. Cancer Res. 2018, 37, 287. [CrossRef] [PubMed]

132. Radisky, E.S.; Radisky, D.C. Matrix metalloproteinase-induced epithelial-mesenchymal transition in breast cancer. J. Mammary Gland Biol. Neoplasia 2010, 15, 201-212. [CrossRef] [PubMed]

133. Kuang, J.; Li, L.; Guo, L.; Su, Y.; Wang, Y.; Xu, Y.; Wang, X.; Meng, S.; Lei, L.; Xu, L.; et al. RNF8 promotes epithelial-mesenchymal transition of breast cancer cells. J. Exp. Clin. Cancer Res. 2016, 35, 88. [CrossRef] [PubMed]

134. Alhosin, M.; Omran, Z.; Zamzami, M.A.; Al-Malki, A.L.; Choudhry, H.; Mousli, M.; Bronner, C. Signalling pathways in UHRF1-dependent regulation of tumor suppressor genes in cancer. J. Exp. Clin. Cancer Res. 2016, 35, 174. [CrossRef] [PubMed]

135. He, M.; Zhou, Z.; Wu, G.; Chen, Q.; Wan, Y. Emerging role of DUBs in tumor metastasis and apoptosis: Therapeutic implication. Pharmacol. Ther. 2017, 177, 96-107. [CrossRef] [PubMed]

136. Frias-Staheli, N.; Giannakopoulos, N.V.; Kikkert, M.; Taylor, S.L.; Bridgen, A.; Paragas, J.; Richt, J.A.; Rowland, R.R.; Schmaljohn, C.S.; Lenschow, D.J.; et al. Ovarian tumor domain-containing viral proteases evade ubiquitin- and ISG15-dependent innate immune responses. Cell Host Microbe 2007, 2, 404-416. [CrossRef] [PubMed]

137. Jiang, J.; Tang, H. Mechanism of inhibiting type I interferon induction by hepatitis B virus $\mathrm{X}$ protein. Protein Cell 2010, 1, 1106-1117. [CrossRef] [PubMed]

138. Li, S.; Zheng, H.; Mao, A.P.; Zhong, B.; Li, Y.; Liu, Y.; Gao, Y.; Ran, Y.; Tien, P.; Shu, H.B. Regulation of virus-triggered signaling by OTUB1- and OTUB2-mediated deubiquitination of TRAF3 and TRAF6. J. Biol. Chem. 2010, 285, 4291-4297. [CrossRef] [PubMed]

139. Kato, K.; Nakajima, K.; Ui, A.; Muto-Terao, Y.; Ogiwara, H.; Nakada, S. Fine-tuning of DNA damage-dependent ubiquitination by OTUB2 supports the DNA repair pathway choice. Mol. Cell 2014, 53, 617-630. [CrossRef]

140. Li, X.Y.; Mao, X.F.; Tang, X.Q.; Han, Q.Q.; Jiang, L.X.; Qiu, Y.M.; Dai, J.; Wang, Y.X. Regulation of Gli2 stability by deubiquitinase OTUB2. Biochem. Biophys. Res. Commun. 2018, 505, 113-118. [CrossRef] [PubMed]

141. Cai, J.Q.; Huang, Y.Z.; Chen, X.H.; Xie, H.L.; Zhu, H.M.; Tang, L.; Yang, Z.M.; Huang, Y.C.; Deng, L. Sonic hedgehog enhances the proliferation and osteogenic differentiation of bone marrow-derived mesenchymal stem cells. Cell Biol. Int. 2012, 36, 349-355. [CrossRef] [PubMed]

142. Harrigan, J.A.; Jacq, X.; Martin, N.M.; Jackson, S.P. Deubiquitylating enzymes and drug discovery: Emerging opportunities. Nat. Rev. Drug Discov. 2018, 17, 57-78. [CrossRef] [PubMed]

143. Poondla, N.; Chandrasekaran, A.P.; Kim, K.S.; Ramakrishna, S. Deubiquitinating enzymes as cancer biomarkers: New therapeutic opportunities? BMB Rep. 2019, 52, 181-189. [CrossRef] [PubMed] 
144. Schauer, N.J.; Magin, R.S.; Liu, X.; Doherty, L.M.; Buhrlage, S.J. Advances in Discovering Deubiquitinating Enzyme (DUB) Inhibitors. J. Med. Chem. 2020, 63, 2731-2750. [CrossRef] [PubMed]

145. Bhattacharya, S.; Chakraborty, D.; Basu, M.; Ghosh, M.K. Emerging insights into HAUSP (USP7) in physiology, cancer and other diseases. Signal Transduct. Target. Ther. 2018, 3, 17. [CrossRef] [PubMed]

146. Colland, F.; Formstecher, E.; Jacq, X.; Reverdy, C.; Planquette, C.; Conrath, S.; Trouplin, V.; Bianchi, J.; Aushev, V.N.; Camonis, J.; et al. Small-molecule inhibitor of USP7/HAUSP ubiquitin protease stabilizes and activates p53 in cells. Mol. Cancer Ther. 2009, 8, 2286-2295. [CrossRef] [PubMed]

147. Reverdy, C.; Conrath, S.; Lopez, R.; Planquette, C.; Atmanene, C.; Collura, V.; Harpon, J.; Battaglia, V.; Vivat, V.; Sippl, W.; et al. Discovery of specific inhibitors of human USP7/HAUSP deubiquitinating enzyme. Chem. Biol. 2012, 19, 467-477. [CrossRef] [PubMed]

148. Altun, M.; Kramer, H.B.; Willems, L.I.; McDermott, J.L.; Leach, C.A.; Goldenberg, S.J.; Kumar, K.G.; Konietzny, R.; Fischer, R.; Kogan, E.; et al. Activity-based chemical proteomics accelerates inhibitor development for deubiquitylating enzymes. Chem. Biol. 2011, 18, 1401-1412. [CrossRef] [PubMed]

149. Tian, X.; Isamiddinova, N.S.; Peroutka, R.J.; Goldenberg, S.J.; Mattern, M.R.; Nicholson, B.; Leach, C. Characterization of selective ubiquitin and ubiquitin-like protease inhibitors using a fluorescence-based multiplex assay format. Assay Drug Dev. Technol. 2011, 9, 165-173. [CrossRef]

150. Chauhan, D.; Tian, Z.; Nicholson, B.; Kumar, K.G.; Zhou, B.; Carrasco, R.; McDermott, J.L.; Leach, C.A.; Fulcinniti, M.; Kodrasov, M.P.; et al. A small molecule inhibitor of ubiquitin-specific protease-7 induces apoptosis in multiple myeloma cells and overcomes bortezomib resistance. Cancer Cell 2012, 22, 345-358. [CrossRef]

151. Fan, Y.H.; Cheng, J.; Vasudevan, S.A.; Dou, J.; Zhang, H.; Patel, R.H.; Ma, I.T.; Rojas, Y.; Zhao, Y.; Yu, Y.; et al. USP7 inhibitor P22077 inhibits neuroblastoma growth via inducing p53-mediated apoptosis. Cell Death Dis. 2013, 4, e867. [CrossRef] [PubMed]

152. Tavana, O.; Li, D.; Dai, C.; Lopez, G.; Banerjee, D.; Kon, N.; Chen, C.; Califano, A.; Yamashiro, D.J.; Sun, H.; et al. HAUSP deubiquitinates and stabilizes N-Myc in neuroblastoma. Nat. Med. 2016, 22, 1180-1186. [CrossRef] [PubMed]

153. Zhang, C.; Lu, J.; Zhang, Q.W.; Zhao, W.; Guo, J.H.; Liu, S.L.; Wu, Y.L.; Jiang, B.; Gao, F.H. USP7 promotes cell proliferation through the stabilization of Ki-67 protein in non-small cell lung cancer cells. Int. J. Biochem. Cell Biol. 2016, 79, 209-221. [CrossRef] [PubMed]

154. Zhang, W.; Zhang, J.; Xu, C.; Zhang, S.; Bian, S.; Jiang, F.; Ni, W.; Qu, L.; Lu, C.; Ni, R.; et al. Ubiquitin-specific protease 7 is a drug-able target that promotes hepatocellular carcinoma and chemoresistance. Cancer Cell Int. 2020, 20, 28. [CrossRef] [PubMed]

155. Weinstock, J.; Wu, J.; Cao, P.; Kingsbury, W.D.; McDermott, J.L.; Kodrasov, M.P.; McKelvey, D.M.; Suresh Kumar, K.G.; Goldenberg, S.J.; Mattern, M.R.; et al. Selective Dual Inhibitors of the Cancer-Related Deubiquitylating Proteases USP7 and USP47. ACS Med. Chem. Lett. 2012, 3, 789-792. [CrossRef]

156. An, T.; Gong, Y.; Li, X.; Kong, L.; Ma, P.; Gong, L.; Zhu, H.; Yu, C.; Liu, J.; Zhou, H.; et al. USP7 inhibitor P5091 inhibits Wnt signaling and colorectal tumor growth. Biochem. Pharmacol. 2017, 131, 29-39. [CrossRef] [PubMed]

157. Fu, C.; Zhu, X.; Xu, P.; Li, Y. Pharmacological inhibition of USP7 promotes antitumor immunity and contributes to colon cancer therapy. OncoTargets Ther. 2019, 12, 609-617. [CrossRef] [PubMed]

158. Morra, F.; Merolla, F.; Napolitano, V.; Ilardi, G.; Miro, C.; Paladino, S.; Staibano, S.; Cerrato, A.; Celetti, A. The combined effect of USP7 inhibitors and PARP inhibitors in hormone-sensitive and castration-resistant prostate cancer cells. Oncotarget 2017, 8, 31815-31829. [CrossRef]

159. Wang, M.; Zhang, Y.; Wang, T.; Zhang, J.; Zhou, Z.; Sun, Y.; Wang, S.; Shi, Y.; Luan, X.; Wang, Y.; et al. The USP7 Inhibitor P5091 Induces Cell Death in Ovarian Cancers with Different P53 Status. Cell Physiol. Biochem. 2017, 43, 1755-1766. [CrossRef]

160. Morra, F.; Merolla, F.; Criscuolo, D.; Insabato, L.; Giannella, R.; Ilardi, G.; Cerrato, A.; Visconti, R.; Staibano, S.; Celetti, A. CCDC6 and USP7 expression levels suggest novel treatment options in high-grade urothelial bladder cancer. J. Exp. Clin. Cancer Res. 2019, 38, 90. [CrossRef] [PubMed]

161. Hu, T.; Zhang, J.; Sha, B.; Li, M.; Wang, L.; Zhang, Y.; Liu, X.; Dong, Z.; Liu, Z.; Li, P.; et al. Targeting the overexpressed USP7 inhibits esophageal squamous cell carcinoma cell growth by inducing NOXA-mediated apoptosis. Mol. Carcinog. 2019, 58, 42-54. [CrossRef] [PubMed] 
162. Carrà, G.; Panuzzo, C.; Torti, D.; Parvis, G.; Crivellaro, S.; Familiari, U.; Volante, M.; Morena, D.; Lingua, M.F.; Brancaccio, M.; et al. Therapeutic inhibition of USP7-PTEN network in chronic lymphocytic leukemia: A strategy to overcome TP53 mutated/deleted clones. Oncotarget 2017, 8, 35508-35522. [CrossRef] [PubMed]

163. Lamberto, I.; Liu, X.; Seo, H.S.; Schauer, N.J.; Iacob, R.E.; Hu, W.; Das, D.; Mikhailova, T.; Weisberg, E.L.; Engen, J.R.; et al. Structure-Guided Development of a Potent and Selective Non-covalent Active-Site Inhibitor of USP7. Cell Chem. Biol. 2017, 24, 1490-1500.e11. [CrossRef] [PubMed]

164. Stolte, B.; Iniguez, A.B.; Dharia, N.V.; Robichaud, A.L.; Conway, A.S.; Morgan, A.M.; Alexe, G.; Schauer, N.J.; Liu, X.; Bird, G.H.; et al. Genome-scale CRISPR-Cas9 screen identifies druggable dependencies in. J. Exp. Med. 2018, 215, 2137-2155. [CrossRef] [PubMed]

165. Turnbull, A.P.; Ioannidis, S.; Krajewski, W.W.; Pinto-Fernandez, A.; Heride, C.; Martin, A.C.L.; Tonkin, L.M.; Townsend, E.C.; Buker, S.M.; Lancia, D.R.; et al. Molecular basis of USP7 inhibition by selective small-molecule inhibitors. Nature 2017, 550, 481-486. [CrossRef] [PubMed]

166. Kategaya, L.; Di Lello, P.; Rougé, L.; Pastor, R.; Clark, K.R.; Drummond, J.; Kleinheinz, T.; Lin, E.; Upton, J.P.; Prakash, S.; et al. USP7 small-molecule inhibitors interfere with ubiquitin binding. Nature 2017, 550, 534-538. [CrossRef] [PubMed]

167. Chen, C.; Song, J.; Wang, J.; Xu, C.; Gu, W.; Sun, H.; Wen, X. Synthesis and biological evaluation of thiazole derivatives as novel USP7 inhibitors. Bioorg. Med. Chem. Lett. 2017, 27, 845-849. [CrossRef] [PubMed]

168. Gavory, G.; O’Dowd, C.R.; Helm, M.D.; Flasz, J.; Arkoudis, E.; Dossang, A.; Hughes, C.; Cassidy, E.; McClelland, K.; Odrzywol, E.; et al. Discovery and characterization of highly potent and selective allosteric USP7 inhibitors. Nat. Chem. Biol. 2018, 14, 118-125. [CrossRef] [PubMed]

169. Yamaguchi, M.; Miyazaki, M.; Kodrasov, M.P.; Rotinsulu, H.; Losung, F.; Mangindaan, R.E.; De Voogd, N.J.; Yokosawa, H.; Nicholson, B.; Tsukamoto, S. Spongiacidin C, a pyrrole alkaloid from the marine sponge Stylissa massa, functions as a USP7 inhibitor. Bioorg. Med. Chem. Lett. 2013, 23, 3884-3886. [CrossRef] [PubMed]

170. Schauer, N.J.; Liu, X.; Magin, R.S.; Doherty, L.M.; Chan, W.C.; Ficarro, S.B.; Hu, W.; Roberts, R.M.; Iacob, R.E.; Stolte, B.; et al. Selective USP7 inhibition elicits cancer cell killing through a p53-dependent mechanism. Sci. Rep. 2020, 10, 5324. [CrossRef] [PubMed]

171. Leger, P.R.; Hu, D.X.; Biannic, B.; Bui, M.; Han, X.; Karbarz, E.; Maung, J.; Okano, A.; Osipov, M.; Shibuya, G.M.; et al. Discovery of Potent, Selective, and Orally Bioavailable Inhibitors of USP7 with In Vivo Anti-Tumor Activity. J. Med. Chem. 2020. [CrossRef]

172. Colombo, M.; Vallese, S.; Peretto, I.; Jacq, X.; Rain, J.C.; Colland, F.; Guedat, P. Synthesis and biological evaluation of 9-oxo-9H-indeno[1,2-b]pyrazine-2,3-dicarbonitrile analogues as potential inhibitors of deubiquitinating enzymes. ChemMedChem 2010, 5, 552-558. [CrossRef] [PubMed]

173. Byun, S.; Lee, S.Y.; Lee, J.; Jeong, C.H.; Farrand, L.; Lim, S.; Reddy, K.; Kim, J.Y.; Lee, M.H.; Lee, H.J.; et al. USP8 is a novel target for overcoming gefitinib resistance in lung cancer. Clin. Cancer Res. 2013, 19, 3894-3904. [CrossRef] [PubMed]

174. Ernst, A.; Avvakumov, G.; Tong, J.; Fan, Y.; Zhao, Y.; Alberts, P.; Persaud, A.; Walker, J.R.; Neculai, A.M.; Neculai, D.; et al. A strategy for modulation of enzymes in the ubiquitin system. Science 2013, 339, 590-595. [CrossRef] [PubMed]

175. MacLeod, G.; Bozek, D.A.; Rajakulendran, N.; Monteiro, V.; Ahmadi, M.; Steinhart, Z.; Kushida, M.M.; Yu, H.; Coutinho, F.J.; Cavalli, F.M.G.; et al. Genome-Wide CRISPR-Cas9 Screens Expose Genetic Vulnerabilities and Mechanisms of Temozolomide Sensitivity in Glioblastoma Stem Cells. Cell Rep. 2019, 27, 971-986.e9. [CrossRef] [PubMed]

176. Lee, M.J.; Lee, B.H.; Hanna, J.; King, R.W.; Finley, D. Trimming of ubiquitin chains by proteasome-associated deubiquitinating enzymes. Mol. Cell. Proteom. 2011, 10, R110.003871. [CrossRef] [PubMed]

177. Massa, F.; Tammaro, R.; Prado, M.A.; Cesana, M.; Lee, B.H.; Finley, D.; Franco, B.; Morleo, M. The deubiquitinating enzyme Usp14 controls ciliogenesis and Hedgehog signaling. Hum. Mol. Genet. 2019, 28, 764-777. [CrossRef] [PubMed]

178. D’Arcy, P.; Brnjic, S.; Olofsson, M.H.; Fryknäs, M.; Lindsten, K.; De Cesare, M.; Perego, P.; Sadeghi, B.; Hassan, M.; Larsson, R.; et al. Inhibition of proteasome deubiquitinating activity as a new cancer therapy. Nat. Med. 2011, 17, 1636-1640. [CrossRef] [PubMed] 
179. Tian, Z.; D'Arcy, P.; Wang, X.; Ray, A.; Tai, Y.T.; Hu, Y.; Carrasco, R.D.; Richardson, P.; Linder, S.; Chauhan, D.; et al. A novel small molecule inhibitor of deubiquitylating enzyme USP14 and UCHL5 induces apoptosis in multiple myeloma and overcomes bortezomib resistance. Blood 2014, 123, 706-716. [CrossRef] [PubMed]

180. Wang, X.; Stafford, W.; Mazurkiewicz, M.; Fryknäs, M.; Brjnic, S.; Zhang, X.; Gullbo, J.; Larsson, R.; Arnér, E.S.; D'Arcy, P.; et al. The 19S Deubiquitinase inhibitor b-AP15 is enriched in cells and elicits rapid commitment to cell death. Mol. Pharmacol. 2014, 85, 932-945. [CrossRef] [PubMed]

181. Cai, J.; Xia, X.; Liao, Y.; Liu, N.; Guo, Z.; Chen, J.; Yang, L.; Long, H.; Yang, Q.; Zhang, X.; et al. A novel deubiquitinase inhibitor b-AP15 triggers apoptosis in both androgen receptor-dependent and-independent prostate cancers. Oncotarget 2017, 8, 63232-63246. [CrossRef] [PubMed]

182. Sooman, L.; Gullbo, J.; Bergqvist, M.; Bergström, S.; Lennartsson, J.; Ekman, S. Synergistic effects of combining proteasome inhibitors with chemotherapeutic drugs in lung cancer cells. BMC Res. Notes 2017, 10, 544. [CrossRef] [PubMed]

183. Didier, R.; Mallavialle, A.; Ben Jouira, R.; Domdom, M.A.; Tichet, M.; Auberger, P.; Luciano, F.; Ohanna, M.; Tartare-Deckert, S.; Deckert, M. Targeting the Proteasome-Associated Deubiquitinating Enzyme USP14 Impairs Melanoma Cell Survival and Overcomes Resistance to MAPK-Targeting Therapies. Mol. Cancer Ther. 2018, 17, 1416-1429. [CrossRef] [PubMed]

184. Ding, Y.; Chen, X.; Wang, B.; Yu, B.; Ge, J. Deubiquitinase inhibitor b-AP15 activates endoplasmic reticulum (ER) stress and inhibits Wnt/Notch1 signaling pathway leading to the reduction of cell survival in hepatocellular carcinoma cells. Eur. J. Pharmacol. 2018, 825, 10-18. [CrossRef] [PubMed]

185. Xia, X.; Liao, Y.; Guo, Z.; Li, Y.; Jiang, L.; Zhang, F.; Huang, C.; Liu, Y.; Wang, X.; Liu, N.; et al. Targeting proteasome-associated deubiquitinases as a novel strategy for the treatment of estrogen receptor-positive breast cancer. Oncogenesis 2018, 7, 75. [CrossRef] [PubMed]

186. Kropp, K.N.; Maurer, S.; Rothfelder, K.; Schmied, B.J.; Clar, K.L.; Schmidt, M.; Strunz, B.; Kopp, H.G.; Steinle, A.; Grünebach, F.; et al. The novel deubiquitinase inhibitor b-AP15 induces direct and NK cell-mediated antitumor effects in human mantle cell lymphoma. Cancer Immunol. Immunother. 2018, 67, 935-947. [CrossRef] [PubMed]

187. Jiang, L.; Sun, Y.; Wang, J.; He, Q.; Chen, X.; Lan, X.; Chen, J.; Dou, Q.P.; Shi, X.; Liu, J. Proteasomal cysteine deubiquitinase inhibitor b-AP15 suppresses migration and induces apoptosis in diffuse large B cell lymphoma. J. Exp. Clin. Cancer Res. 2019, 38, 453. [CrossRef] [PubMed]

188. Yu, Y.; Zhao, Y.; Fan, Y.; Chen, Z.; Li, H.; Lu, J.; Guo, K.; Woodfield, S.E.; Vasudevan, S.A.; Yang, J.; et al. Inhibition of Ubiquitin-Specific Protease 14 Suppresses Cell Proliferation and Synergizes with Chemotherapeutic Agents in Neuroblastoma. Mol. Cancer Ther. 2019, 18, 1045-1056. [CrossRef]

189. Shukla, N.; Somwar, R.; Smith, R.S.; Ambati, S.; Munoz, S.; Merchant, M.; D'Arcy, P.; Wang, X.; Kobos, R.; Antczak, C.; et al. Proteasome Addiction Defined in Ewing Sarcoma Is Effectively Targeted by a Novel Class of 19S Proteasome Inhibitors. Cancer Res. 2016, 76, 4525-4534. [CrossRef] [PubMed]

190. Wang, X.; D'Arcy, P.; Caulfield, T.R.; Paulus, A.; Chitta, K.; Mohanty, C.; Gullbo, J.; Chanan-Khan, A.; Linder, S. Synthesis and evaluation of derivatives of the proteasome deubiquitinase inhibitor b-AP15. Chem. Biol. Drug Des. 2015, 86, 1036-1048. [CrossRef] [PubMed]

191. Vogel, R.I.; Pulver, T.; Heilmann, W.; Mooneyham, A.; Mullany, S.; Zhao, X.; Shahi, M.; Richter, J.; Klein, M.; Chen, L.; et al. USP14 is a predictor of recurrence in endometrial cancer and a molecular target for endometrial cancer treatment. Oncotarget 2016, 7, 30962-30976. [CrossRef] [PubMed]

192. Mazurkiewicz, M.; Hillert, E.K.; Wang, X.; Pellegrini, P.; Olofsson, M.H.; Selvaraju, K.; D’Arcy, P.; Linder, S. Acute lymphoblastic leukemia cells are sensitive to disturbances in protein homeostasis induced by proteasome deubiquitinase inhibition. Oncotarget 2017, 8, 21115-21127. [CrossRef] [PubMed]

193. Wang, X.; Mazurkiewicz, M.; Hillert, E.K.; Olofsson, M.H.; Pierrou, S.; Hillertz, P.; Gullbo, J.; Selvaraju, K.; Paulus, A.; Akhtar, S.; et al. The proteasome deubiquitinase inhibitor VLX1570 shows selectivity for ubiquitin-specific protease-14 and induces apoptosis of multiple myeloma cells. Sci. Rep. 2016, 6, 26979. [CrossRef] [PubMed]

194. Rowinsky, E.K.; Paner, A.; Berdeja, J.G.; Paba-Prada, C.; Venugopal, P.; Porkka, K.; Gullbo, J.; Linder, S.; Loskog, A.; Richardson, P.G.; et al. Phase 1 study of the protein deubiquitinase inhibitor VLX1570 in patients with relapsed and/or refractory multiple myeloma. Investig. New Drugs 2020. [CrossRef] [PubMed] 
195. Lee, B.H.; Lee, M.J.; Park, S.; Oh, D.C.; Elsasser, S.; Chen, P.C.; Gartner, C.; Dimova, N.; Hanna, J.; Gygi, S.P.; et al. Enhancement of proteasome activity by a small-molecule inhibitor of USP14. Nature 2010, 467, 179-184. [CrossRef]

196. Wang, Y.; Jiang, Y.; Ding, S.; Li, J.; Song, N.; Ren, Y.; Hong, D.; Wu, C.; Li, B.; Wang, F.; et al. Small molecule inhibitors reveal allosteric regulation of USP14 via steric blockade. Cell Res. 2018, 28, 1186-1194. [CrossRef] [PubMed]

197. Xia, X.; Huang, C.; Liao, Y.; Liu, Y.; He, J.; Guo, Z.; Jiang, L.; Wang, X.; Liu, J.; Huang, H. Inhibition of USP14 enhances the sensitivity of breast cancer to enzalutamide. J. Exp. Clin. Cancer Res. 2019, 38, 220. [CrossRef] [PubMed]

198. Han, K.H.; Kwak, M.; Lee, T.H.; Park, M.S.; Jeong, I.H.; Kim, M.J.; Jin, J.O.; Lee, P.C. USP14 Inhibition Regulates Tumorigenesis by Inducing Autophagy in Lung Cancer In Vitro. Int. J. Mol. Sci. 2019, 20, 5300. [CrossRef] [PubMed]

199. Lospinoso Severini, L.; Quaglio, D.; Basili, I.; Ghirga, F.; Bufalieri, F.; Caimano, M.; Balducci, S.; Moretti, M.; Romeo, I.; Loricchio, E.; et al. A Smo/Gli Multitarget Hedgehog Pathway Inhibitor Impairs Tumor Growth. Cancers 2019, 11, 1518. [CrossRef] [PubMed]

200. Infante, P.; Mori, M.; Alfonsi, R.; Ghirga, F.; Aiello, F.; Toscano, S.; Ingallina, C.; Siler, M.; Cucchi, D.; Po, A.; et al. Gli1/DNA interaction is a druggable target for Hedgehog-dependent tumors. EMBO J. 2015, 34, 200-217. [CrossRef]

201. Atwood, S.X.; Sarin, K.Y.; Whitson, R.J.; Li, J.R.; Kim, G.; Rezaee, M.; Ally, M.S.; Kim, J.; Yao, C.; Chang, A.L.; et al. Smoothened variants explain the majority of drug resistance in basal cell carcinoma. Cancer Cell 2015, 27, 342-353. [CrossRef] [PubMed]

202. Danial, C.; Sarin, K.Y.; Oro, A.E.; Chang, A.L. An Investigator-Initiated Open-Label Trial of Sonidegib in Advanced Basal Cell Carcinoma Patients Resistant to Vismodegib. Clin. Cancer Res. 2016, 22, 1325-1329. [CrossRef] [PubMed]

203. Wang, C.; Wu, H.; Katritch, V.; Han, G.W.; Huang, X.P.; Liu, W.; Siu, F.Y.; Roth, B.L.; Cherezov, V.; Stevens, R.C. Structure of the human smoothened receptor bound to an antitumour agent. Nature 2013, 497, 338-343. [CrossRef] [PubMed]

204. Le Clorennec, C.; Lazrek, Y.; Dubreuil, O.; Sampaio, C.; Larbouret, C.; Lanotte, R.; Poul, M.A.; Barret, J.M.; Prost, J.F.; Pèlegrin, A.; et al. ITCH-dependent proteasomal degradation of c-FLIP induced by the anti-HER3 antibody 9F7-F11 promotes DR5/caspase 8-mediated apoptosis of tumor cells. Cell Commun. Signal. 2019, 17, 106. [CrossRef] [PubMed]

205. Le Clorennec, C.; Lazrek, Y.; Dubreuil, O.; Larbouret, C.; Poul, M.A.; Mondon, P.; Melino, G.; Pèlegrin, A.; Chardès, T. The anti-HER3 (ErbB3) therapeutic antibody 9F7-F11 induces HER3 ubiquitination and degradation in tumors through JNK1/2- dependent ITCH/AIP4 activation. Oncotarget 2016, 7, 37013-37029. [CrossRef] [PubMed]

206. Nguyen, H.T.; Kugler, J.M.; Cohen, S.M. DUB3 Deubiquitylating Enzymes Regulate Hippo Pathway Activity by Regulating the Stability of ITCH, LATS and AMOT Proteins. PLoS ONE 2017, 12, e0169587. [CrossRef] [PubMed]

207. Mouchantaf, R.; Azakir, B.A.; McPherson, P.S.; Millard, S.M.; Wood, S.A.; Angers, A. The ubiquitin ligase itch is auto-ubiquitylated in vivo and in vitro but is protected from degradation by interacting with the deubiquitylating enzyme FAM/USP9X. J. Biol. Chem. 2006, 281, 38738-38747. [CrossRef] [PubMed]

208. Kim, Y.; Kim, W.; Song, Y.; Kim, J.R.; Cho, K.; Moon, H.; Ro, S.W.; Seo, E.; Ryu, Y.M.; Myung, S.J.; et al. Deubiquitinase YOD1 potentiates YAP/TAZ activities through enhancing ITCH stability. Proc. Natl. Acad. Sci. USA 2017, 114, 4691-4696. [CrossRef] [PubMed]

209. Bufalieri, F.; Infante, P.; Bernardi, F.; Caimano, M.; Romania, P.; Moretti, M.; Lospinoso Severini, L.; Talbot, J.; Melaiu, O.; Tanori, M.; et al. ERAP1 promotes Hedgehog-dependent tumorigenesis by controlling USP47-mediated degradation of $\beta$ TrCP. Nat. Commun. 2019, 10, 3304. [CrossRef] [PubMed]

(C) 2020 by the authors. Licensee MDPI, Basel, Switzerland. This article is an open access article distributed under the terms and conditions of the Creative Commons Attribution (CC BY) license (http://creativecommons.org/licenses/by/4.0/). 